\title{
Alkali-silica expansion potentiality of Erzeni riverbed aggregates (Albania) and the risk of corrosion in concretes produced with them
}

\begin{abstract}
The environmental and fuel efficiency reasons led the industry of building raw materials to develop new technologies for production of cements. The cements being produced have high alkali content which in combination with some sorts of aggregates may influence the chemistry of the concrete mixture that may cause long term harmful effects to concrete structures.

In this paper it is succinctly reviewed a part of scientific research work done on the possibility of the manifestation of the harmful effects caused by Alkali-Silica Reaction (ASR) on concretes made of high alkali cements and riverbed aggregates of Albania, in particular of those of Erzeni River, which is the most exploited one in Albania. The treatment of this topic has been a necessity and is considered very important for building industry in Albania, where traditionally low alkali cements have been produced and used. Especially in the period of transition, when high alkali cements started to be used both from import and domestic production, it is considered very important the study of the suitability of the riverbed aggregates in concrete produced with high alkali content cement since there are no ways of preventing ASR after the concrete has been placed.

The results and recommendations of this study serve to increase the builder's awareness of the need of proper investigation, from this point of view, of the raw materials prior to construction. They also contribute to environment protection both by recommending alternative aggregates to riverbed ones and by helping to avoid the degradation, in timeframe, of concrete structures.
\end{abstract}

Keywords: Alkali-Silica Reaction (ASR), riverbed aggregates, chert, siliceous aggregate, limestone aggregate.

\section{INTRODUCTION}

Deterioration of concrete structures because of alkaline attack of aggregates and ASR is causing a great concern in many countries all over the world and in almost all European countries, both because of the potential threat to the service life of concrete structures and the extra costs of repairing the structures affected by this reaction.

ASR is a so-called heterogeneous chemical reaction between sodium and potassium hydroxides in cement paste and certain alkaline reactive amorphous minerals in aggregate producing a hygroscopic gel which, when moisture is present, absorbs water and expands causing degradation of appearance (pattern cracking and excessive expansion), deterioration in concrete strength and effecting structural behavior of concrete structures. Durability of concrete structures may not be directly affected by ASR, but expansive cracking of cover concrete may increase the risk of reaching steel reinforcements by providing a route for water, air and chlorides. It will also increase possibility of freeze-thaw attack.

Author's address: Department of Industrial Chemistry, Faculty of Natural Sciences, Albania

Received for Publication: 17. 07. 2014.

Accepted for Publication: 21. 09. 2014.
There are three essential factors that cause the Alkali-Silica Reaction: alkalis, certain alkaline reactive amorphous silica minerals, and moisture having the role of the reagent and a transport media. The alkalis are mainly supplied by the cement paste of concrete or can under certain circumstances be derived from the aggregate material, mix water, ground water, chemical admixtures, pigments, etc. Moisture is mostly provided by "exposure conditions", e.g. atmospheric water or service conditions. The mechanism of silica dissolution is not very much controlled by alkalis, as by dissolved $\mathrm{OH}$-ions breaking silica bonds which then recombine with present alkali-ions.

The main contributor to the alkalinity of pore solution is the soluble alkali in cement.

Wet cement is a very active alkaline chemical environment and chemical reaction occurs between the aggregate particles and the cement filler. Cements with an alkali content $\left(\mathrm{Na}_{2} \mathrm{O}+\mathrm{K}_{2} \mathrm{O}\right)$ below $0.6 \%$ (low-alkali cements) has been found to cause a little expansion with reactive aggregates. On the contrary, the high alkali cement is a very active alkaline chemical environment for some alkali reactive varieties of silica in aggregate, i.e. non-crystalline or imperfectly crystalline silica (such as opal, chalcedony, chert, tridimite, christobalite), strained quartz or microcrystalline quartz (such as quartzite), glassy to cryptocrystalline matrix of igneous rocks (such as pumice), etc. Silica is an amphoteric 
material which means it dissolves at extreme $\mathrm{pH}$ values, in strongly acidic or strongly alkaline conditions and less around neutral $\mathrm{pH}$. The dissolution of silica is affected by $\mathrm{pH}$ as well as by foreign species in pore solution, foreign species and hydrous species in the solid silica, polymorphism of quartz, the quality of crystal lattice, silica particle size, coexisting minerals, etc.

The reasons for the recent apparently prevalence of damage of concrete from ASR are considered to be the changes in concrete technology (concrete mixes richer in cements are being used, producing higher total alkali contents in concrete) as well as in cement technology.

Changes in cement production methods (especially in developed countries, but even in developing ones) in order to comply with environmental regulations have placed controls on the emission of stack gases into the atmosphere. Therefore, the tendency is that the alkali content of cement to be increased, because the dusts from kiln (rich of alkali) are recycled and returned back to process adding the alkali load of cement. On the other hand, in order to use fuel more efficiently, the wet process of cement production (where alkalis were partly leached) is being abandoned and is being substituted by dry process. So, the low-alkali cements are unlikely to be produced and found in the market.

In Albania, until the start of political transitory period (year 1990), the construction sector needs were satisfied with in country produced cements.

After 1990, in the conditions of the upset of the domestic cement production caused by closure of several of cement factories, the cement needs have been compensated with cement imported from other countries, like Italy, Croatia, Greece, etc.

Later on, even in Albania, the previous wet process (Fushe Kruja Cement Factory) has been changed towards dry clinker production process and the other new cement factories are based on dry cement production process, too.

So, nowadays in Albania, high alkali content cements are being used in concrete and this is likely to happen even in the future.

In order to evaluate the potential risk of the already built structures of the time period and for comparison reasons, we have examined the chemical content of cements produced in Albania during the period of time 1980-1995, in the factories of F. Kruja, Vlora and Elbasan, as well as their raw materials.

Also, we have analyzed several of imported cements, used in Albania in the last decades.

Therefore, in the conditions of using of these high-alkali cements and guided by the world experience and recommendations of many scientific authorities of this field, we proceeded this research to determine if any potential risk exists for manifestation of ASR in concretes prepared with the riverbed aggregates of Albania, to evaluate their potential reactivity in concrete mixtures made with high alkali cement and, based on the classification of their reactivity, to recommend builders the riverbed aggregates that they must avoid to use in concrete production; especially in hydraulic structures.

It is significant to point out that, this is the first work where the topic of the alkali-silica expansion potentially of riverbed aggregates in Albania and the risk of corrosion in concretes produced with them is considered and evaluated.

In this regard, initially we studied the behaviour of aggregates taken from the main riverbeds of Albania.

The experiments are carried out according to the method of continuity of tests (UNI 8520-22) that includes the petrographic examinations of aggregates, the accelerated expansion tests and longterm expansion tests. The data taken from the experimental behavior of samples in these tests are graphically shown and statistically analyzed and commented.

The high values of expansions and the visible cracks of the samples of Erzen (Tirana capital) and Osum (Berat city) riverbed aggregates classified them as potentially alkali-reactive aggregates [1].

Out of these two potentially alkali-reactive aggregates we choose the Erzeni riverbed aggregates for further more complex study because, being in the vicinity of two big cities Tirana and Durres, they are target of high exploitation due to big demand for aggregates from the ever-growing building industry in this region.

For this study the aggregate samples are taken at random along Erzen riverbed from Elbasan to Durres.

Based on the expansion values, a classification of these aggregates from innocuous to moderate reactive aggregates was made [2-11].

But this classification was not definitive taking into account that the aggregates containing more than $2 \%$ of reactive constituents in the form of porous chert, flint or chalcedony (that is the case of Erzeni riverbed aggregates with above $2 \%$ mineral chert) may exhibit the so-called "pessimum effect" in accelerated mortar bar tests and can yield misleading results and inappropriate approval of certain active aggregates to be used in concrete production.

According to Hobbs and Shayan, the reason for "the pessimum content" of aggregate in the standard accelerated tests, is that for a certain content of alkalis, the expansion of mortar bars is increased as the content of active aggregate is increased up to a point ("negative content"), beyond which there 
are no more available alkalis to form expansive gel. At higher contents of active aggregate the amount of alkalis become so low or dilute in mortar that occur just a slight or not at all expansion.

So, the latent active character of some Erzeni riverbed aggregates is pointed out during the experimental determination of the so-colled "pessimum content". The results of continuity of tests are confirmed by strength tests and durability on freeze-thaw tests.

The evidence of "pessimum effect" clearly shows that the mixture of aggregates of different types (the so-called "sweetening of aggregates") used as one of possible ways of minimizing the negative effects of Alkali-Silica Reaction in concrete, not always brings up to positive results [12-14].

Since the aggregate with its specific mineralogical composition has a direct influence in concrete quality, in addition to the expansion tests of concrete samples produced with Erzeni riverbed aggregates, some mineralogical investigations of these aggregates and the concretes produced with them are carried out to evaluate the alkali-silica potential reactivity of these aggregates and the quality of concrete produced with them $[15,16]$.

Thin sections of concrete samples, that were treated in expansion tests, are examined on polarized-light microscope and the main raw materials of concrete (aggregate and cement paste) are studied.

Also, the interior of concrete samples are examined by SEM to identify the presence of internal cracking and the mapping of elements within the active aggregate particles.

An attempt is made to study the influence of concrete mix design on the ASR, using Erzeni riverbed aggregates.

Through 31 sets of experiments, carried out with different concrete mixtures, is investigated the influence on the expansion caused by Alkali Silica Reaction of water to cement ratio, aggregate to cementing material ratio and the percentage of copper slag as well as the concentration of alkaline in the experimenting environment.

The findings identified the content of slag and the aggregate to cementing material ratio as significantly contributing to ASR expansion with a less strong influence of two other factors. Response surface modeling has identified a negative trend of the two principal factors and a direct trend of the other factors [14, 17 - 19].

\section{SUMMARISED RESULTS AND DISCUSSION}

\section{As object of experimentations are selected riverbed aggregates. Why?}

The aggregates traditionally used in concrete production in Albania are riverbed aggregates which are plenty, easy accessible and near the main towns that makes them attractive to builders. In Albanian language they are called "inerte" that means non-reactive ingredient in concrete production process but their "non-reactivity" is to be questioned in certain conditions.

In the other hand, scientific researchers have found that the aggregates containing more than $4 \%$ total silica, when used in concrete production, may manifest the Alkali-Silica Reaction (ASR).

In Albania there are two options of aggregates for use as fillers in concrete production; the riverbed aggregates and the artificial aggregates prepared by comminuting the limestone rocks taken from limestone quarries.

Since the riverbed aggregates of Albania are mainly siliceous aggregates (total silica content is $25-65 \%$ ) and the total silica content of limestone aggregates is low (up to $0.5 \%$ ); we chose to study the ASR potentiality expansion of the riverbed aggregates without considering the limestone ones; which in our experimental work are used only for comparison reasons and as additive aggregates [2].

\section{The actual possibility of the Alkali-Silica Reaction (ASR) or so-called "cancer of concrete" in concrete structures in Albania.}

In Albania, before the transition period (1990 1995), in country produced cements are used.

These cements, produced in Fushe-Kruja, Vlora, Elbasan, Shkodra, etc. factories, had low alkali content that was as the result of the wet technological process (where the kiln dust, abundant with alkalies, was partially returned back to process, but most of it was discharged into atmosphere) and because of the low content of alkali in cement raw materials (limestones and clays).

Most of the concrete structures are made with riverbed aggregates and in country produced cements. In these concrete structures there was never noticed any problem that could be related to ASR. Probably this is dedicated to low alkali content of cements used in that time.

After 1990, with the restoration of the market economy and the policy of open doors, the imported cements from Italy, Greece, Croatia, etc. started to replace domestic cement production.

Due to environmental restrictions and cost of production, the imported cements had higher alkali content. The trend of producing high alkali content cements is followed by the reactivated Albanian cement industry and nowadays almost all cement used in Albania is with high alkali content.

For the evaluation of the possibility of the manifestation of ASR (or as it is called "the cancer of concrete") in Albania we started with the examination of the cements used and likely to be used dividing them into 2 periods; before and after 1995. 
The second period is not much different from today and the foreseen future trend.

The equivalent alkali content of these cements is represented in the Graphic 1. In the first row are represented some in country produced cements (the mean alkali content of these cements resulted to be up to $1 \%$ ) and raw materials used for their production before 1995. Whereas, in the second row is represented the $\mathrm{Na}_{2} \mathrm{O}_{\text {eq }}$ content of some imported cements used after 1995 (the mean alkali content resulted to be $1.8 \%$ ) in Albania [1, 2].

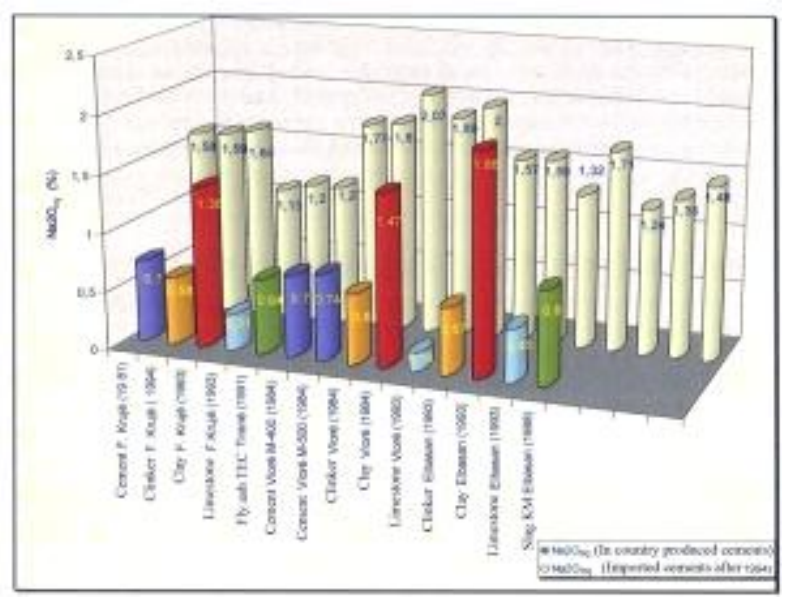

Figure $1-\mathrm{Na}_{2} \mathrm{O}_{e q}$ content of some in country produced cements before 1995 and their raw materials, as well as the $\mathrm{Na}_{2} \mathrm{O}_{\text {eq }}$ content of some imported cements after 1995

From the results of cement analyses, shown in Figure 1, and the general knowledge on the manifestation of ASR, we would preliminarily evaluate that the risk of manifestation of deterioration effects of ASR in concrete structures that have been built before 1995 is very low to inexistent, while the risk could increase to medium or high for structures built after 1995 or in process of building without the proper check of the reactivity of aggregates.

Since there is a considerable potential risk of ASR manifestation in concretes to be produced with nowadays available cements and riverbed aggregates of Albania, the right solution is the prior check of aggregates and the use of non-reactive aggregates only; especially in hydraulic concrete structures.

\section{Potential risk manifestation of Alkali-Silica}

Reactions (ASR) in concretes prepared by aggregates from different riverbeds in Albania

In Albania there are many rivers, aggregates of which are used as fillers for mortar and concrete production as: Erzen, Tërkuza, River of Tirana, Shkumbin, Fan, Mat, Kir, Drin, Devoll, Vjosa, Osum, Shushica, Bistrica, Drino and Valbona.

In our study, for the determination of potential alkali-silica reactivity of aggregates in presence of alkali, the samples are collected from the riverbeds of eight main rivers of Albania (Erzen, Shkumbin, Fan, Mat, Kir, Drin, Vjosa and Osum). The samples are taken at random in the units of aggregate processing. The aggregate samples are collected in three different levels of each aggregate heap of the processing unit. They are mixed together, homogenized and representative samples till 5 kilograms are prepared.

Tests are carried out according to the Italian Standard UNI 8520-22 "Determination of potential reactivity of aggregates in presence of alkali", 1999. According to this method, this determination must be performed by means of three tests, done in continuity:

- Expert petrographic examination of aggregates

- Accelerated expansion testing of mortar bars made from these aggregates

- Long term expansion testing of such mortar bars

If petrographic examination does not indicate the presence of alkali-active minerals, the examined aggregate may be considered non alkalireactive and it is considered innocuous to be used in concrete. Alkali-reactive minerals are silicon minerals where silica is in a reactive form, such as opal, etc. They are characterized by a random network of tetraedra with irregular spaces between the groups of molecules. The reactive forms have a high internal surface area, making them much more susceptible to surface hydration and to breakage by alkali cations of silicon-oxygen bond that bind together the silicon-oxygen tetraedra.

If petrographic examination proves the presence of alkali-reactive minerals, then the accelerated expansion testing of mortar bars must be carried out. If the expansion does not exceed the limit of $0.1 \%$, after 14 days of exposure to the sodium hydroxide $1 \mathrm{~N}$ solution at $80^{\circ} \mathrm{C}$, the aggregate is considered to be non-reactive.

The long-term expansion test must be carried out if expansion after accelerated expansion test lies at the uncertainty zone (0.1-0.2\%). Aggregate is considered appropriate to be used in concrete, if the expansion does not exceed the limit of $0.08 \%$, after 3 months of exposure to water, at $38^{0} \mathrm{C}$ or of $0.1 \%$ after 6 months at the same conditions [3].

From petrographic examination of aggregates tested, resulted that aggregates of some of rivers had reactive mineral, chert (a reactive mineral in which predominate microcrystalline chalcedony and porous opaline silica, with variable percent of cryptocrystalline quartz) in these quantities:

Samples of Ezen aggregate, Ko: $\quad 4 \%$

Samples of Shkumbin aggregate: $\quad 3 \%$

Samples of Fan aggregate: $\quad 2 \%$

Samples of Drin aggregate: $\quad 4 \%$

Samples of Osum aggregate: $\quad 2 \%$ 
Accelerated test has been carried out for the samples of aggregates of all rivers, regardless of the presence of chert in them.

The aggregates were crushed and their granulometric content was regulated to fulfill the following requirements: $10 \%$ (by mass) - grains of $2 \div 4$ $\mathrm{mm} ; 25 \%$ (by mass) - grains of $1 \div 2 \mathrm{~mm} ; 25 \%$ (by mass) - grains of $0.5 \div 1 \mathrm{~mm} ; 25 \%$ (by mass) - grains of $0.25 \div 0.5 \mathrm{~mm} ; 15 \%$ (by mass) - grains of $0.125 \div 0.25 \mathrm{~mm}$.

Portland cement, with alkalis content of $0.78 \%$, $\mathrm{CaO}_{\text {free }}$ content of $0.48 \%, \mathrm{SO}_{3}$ content of $3.38 \%$ and specific surface $4041 \mathrm{~cm}^{2} / \mathrm{g}$ is used for the tests.

The cement to aggregate ratio was 1 to 2.25 and the water to cement ratio was 0.47 . For each aggregate, bars of $4 \times 4 \times 16 \mathrm{~cm}$ were cast. After 24 hours we demoulded the bars and submerged them in a plastic container with water. Afterwards, the container was closed and held at $80^{\circ} \mathrm{C}$ for 24 hours. Immediately after the bars were taken out of the water, we measured their length (zero measurement).

After the first length measurement, a part of bars were left for hardening in natural conditions and the others were submerged in $1 \mathrm{~N} \mathrm{NaOH}$ solution, at $80^{\circ} \mathrm{C}$. During the hardening time of 14 days in these conditions, we measured the expansions of bars on every working day at the same time. The average daily length change of treated bars is measured with a precision of a $0.002 \mathrm{~mm}$ and it is presented graphically as the function of the time.

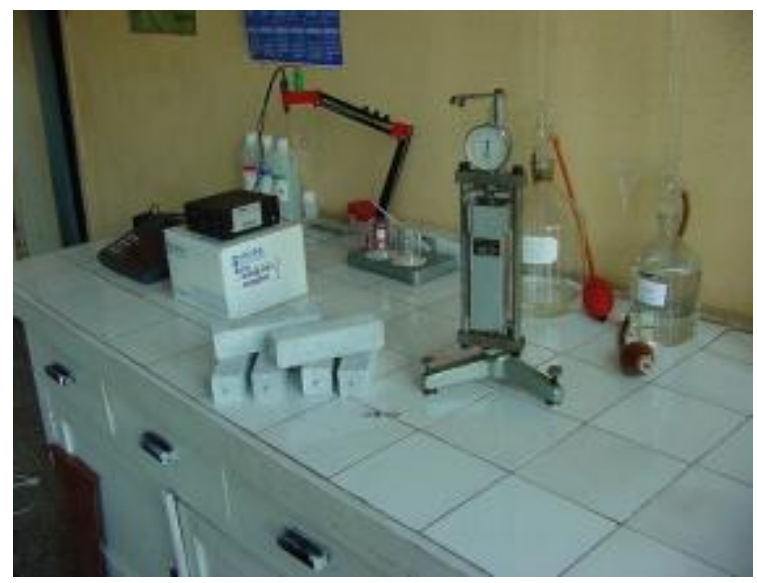

Figure 2 - The apparatus used for longitudinal expansion measurements of mortar bars

Experimental results of average daily expansions for treated bars prepared by aggregates of eight different riverbeds are presented in Figure 3.

From Figure 3, it is evident that the aggregates behavior in the treated bars is different. The expansions of bars prepared with the aggregates of Erzen and Osum riverbeds are respectively $0.287 \%$ and $0.291 \%$, while the expansions of the bars prepared with aggregates of the other riverbeds are less than $1 \%$.

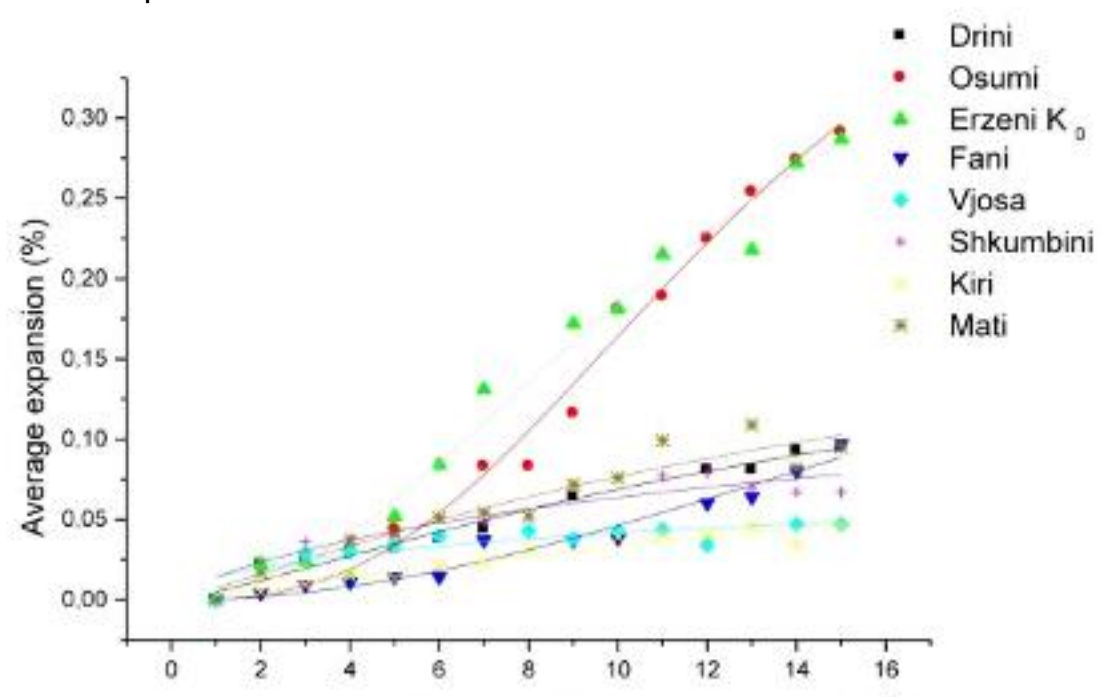

Days of treatment of prisms in $\mathrm{NaOH} 1 \mathrm{~N}$ solutions, $80^{\circ} \mathrm{C}$

Figure 3 - The average length change of treated bars as the function of time

These experimental results led us to classify the aggregates into two types:

The first type include the aggregates of Erzen and Osum rivers with average expansion over $0.2 \%$ that according to the Standard used for the tests are considered as potentially alkali-reactive.
The second type include the aggregates of Drin, Fan, Vjosa, Shkumbini, Kiri and Mati riverbeds with average expansion of less than $0.1 \%$ that are considered as non-reactive.

These experimental results confirmed the need of the use of the method of the continuity of tests foreseen in the Standard because regardless of the 
presence of chert in samples of aggregates of Shkumbin, Fan and Drin, the final expansions of mortar bars prepared by them were under $0.1 \%$.

In fact, there is a complex relation between the quantity and fineness of reactive material in aggregate with the degree of expansion caused by its presence. The evaluation of graphics is done according to $\mathrm{Chi}^{\wedge} 2$ test. For a probability $\alpha=0.95$ and $\mathrm{k}=1$, the calculated $\mathrm{Chi}^{\wedge} 2$ values were lower than tabular ones. This shows a good accordance of graphics with experimental values.

The visual examination showed that only the treated bars of Erzen and Osum were full of map pattern crackings, which are typical for ASR. The flexure strengths of these mortar bars were decreased at the values $33.15 \%$ and $26.76 \%$; the compressive strengths were decreased $32.4 \%$ and $29.6 \%[1,3,13]$.

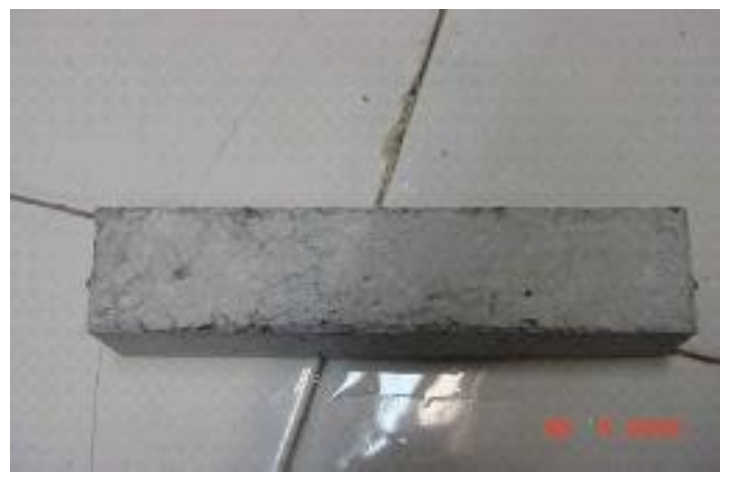

Figure 4 - One of the bars made with aggregates of Erzen riverbed after 14 days treatment in $1 \mathrm{~N} \mathrm{NaOH}$ solution, at $80^{\circ} \mathrm{C}$

\section{The alcaline attack of Erzeni riverbed} aggregates used in concrete mixtures and the risk of potential manifestation of Alkali-Silica Reactions (ASR) in concretes prepared by them

From the above experimental study we found that, out of the riverbed aggregates studied, two of them Erzeni and Osum riverbed aggregates, classified by us as first type aggregates, are potentially dangerous to be used in concrete production.

The aggregates of these two riverbeds are traditionally used for concrete production and actually they are very attractive to builders due to their location.

In particular the aggregates of Erzeni riverbed are highly exploited during the last decades and are a target for more exploitation nowadays and in future due to vicinity with two biggest cities of Albania which are in a process of fast growing. The trend of high multi-floors buildings, massive structures and new complex constructive elements that are in these cities' planning requires an urgent verification of the suitability of aggregates to be used in these concrete structures.

For these reasons out of the two potentially alkali-reactive aggregates we choose the Erzeni riverbed aggregates for further more complex study.

So, our further study aimed at evaluating and classifying of Erzeni riverbed aggregates, regarding their Alkali-Silica Reactivity. The samples are taken along Erzen riverbed from lba village (near Elbasan) to Shijak village (near Durres). The samples are taken at random in 12 centers of aggregate processing facilities along Erzeni riverbed.

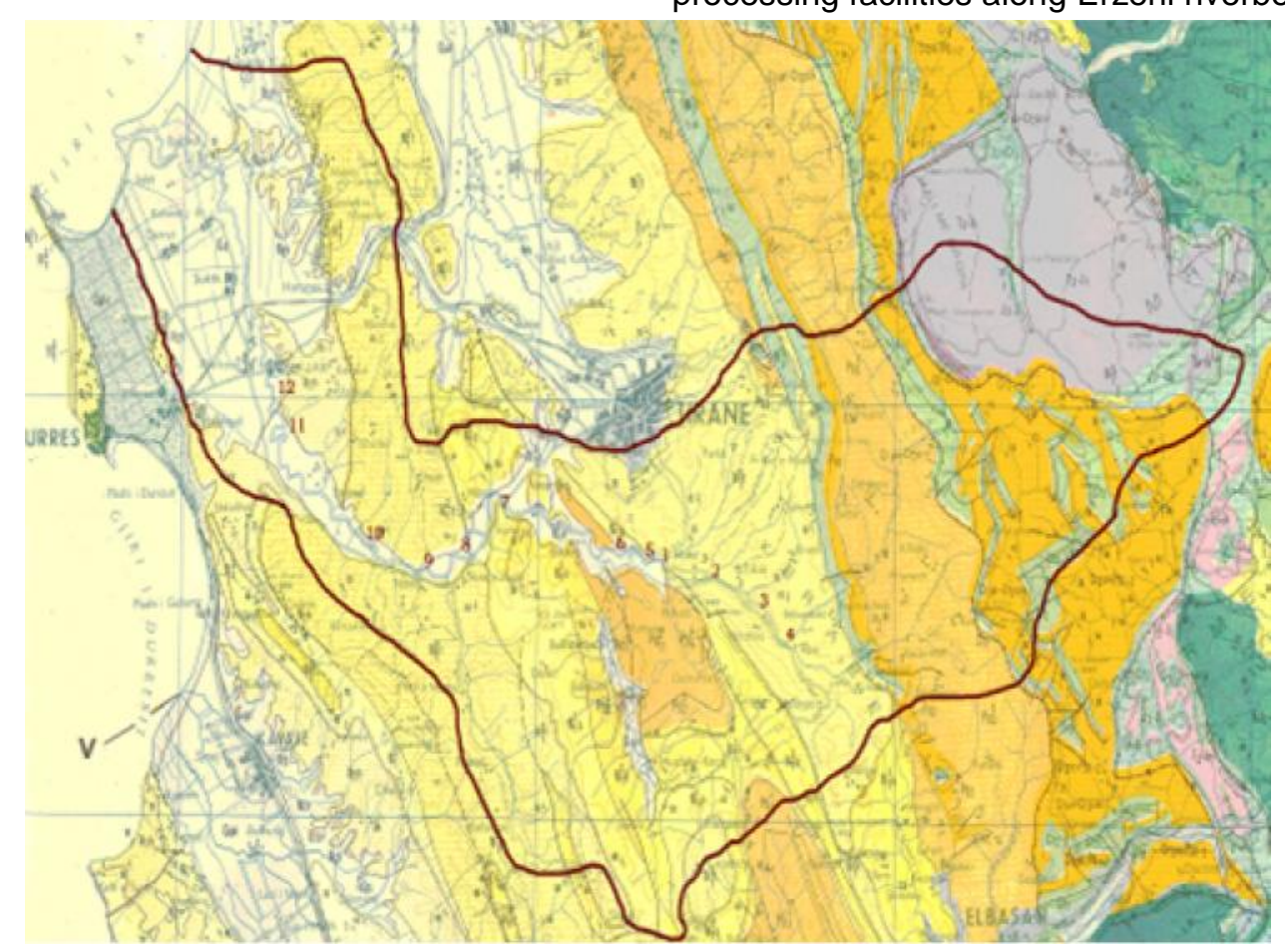

Figure 5 - The map of Erzeni river basin and the places where samples are taken along its riverbed 
For preparing of the representative aggregate samples, the same procedure described above is used; as well as the same standard, mentioned above, is used for the determination of the alkali silica potentiality of the aggregates.

The aggregate samples are named with numbers and the zones along Erzeni riverbed where they are taken from are indicated on the map, Figure 5.
The main results of the experimental findings of the petrographic examinations, the accelerated and long-term (three months) tests for the 12 aggregate samples are submitted below in the form of summarized tables and graphics.

The mineralogical examination of the aggregates is carried out with binocular-stereoscopic microscope and the mineral content as well as relative quantities of constituent minerals of each sample of aggregate are determined.

Table 1 - The mineralogical content of aggregate samples

\begin{tabular}{|l|c|c|c|c|c|c|c|c|c|c|c|c|}
\hline & \multicolumn{10}{|c|}{ Mineral content in \% } \\
\hline Samples & $\mathbf{A}_{\mathbf{1}}$ & $\mathbf{A}_{\mathbf{2}}$ & $\mathbf{A}_{\mathbf{3}}$ & $\mathbf{A}_{\mathbf{4}}$ & $\mathbf{A}_{\mathbf{5}}$ & $\mathbf{A}_{\mathbf{6}}$ & $\mathbf{A}_{\mathbf{7}}$ & $\mathbf{A}_{\mathbf{8}}$ & $\mathbf{A}_{\mathbf{9}}$ & $\begin{array}{c}\mathbf{A}_{\mathbf{1}} \\
\mathbf{0}\end{array}$ & $\mathbf{A}_{\mathbf{1 1}}$ & $\begin{array}{c}\mathbf{A}_{\mathbf{1}} \\
\mathbf{2}\end{array}$ \\
\hline Calcite & 18 & 19 & 25 & 20 & 25 & 20 & 22 & 30 & 30 & 36 & 28 & 30 \\
\hline Quartz & 28 & 23 & 22 & 18 & 26 & 25 & 18 & 25 & 27 & 28 & 23 & 27 \\
\hline Chert & $1-2$ & $2-3$ & $1-2$ & 2 & $1-2$ & 2 & $2-3$ & 2 & 3 & 2 & 2 & 2 \\
\hline Calcareous Clay & 38 & 42 & 40 & 45 & 35 & 40 & 35 & 30 & 30 & 28 & 40 & 34 \\
\hline Others (coal, slag, waste, etc) & 14 & 13 & 11 & 15 & 13 & 13 & 22 & 11 & 10 & 7 & 7 & 7 \\
\hline
\end{tabular}

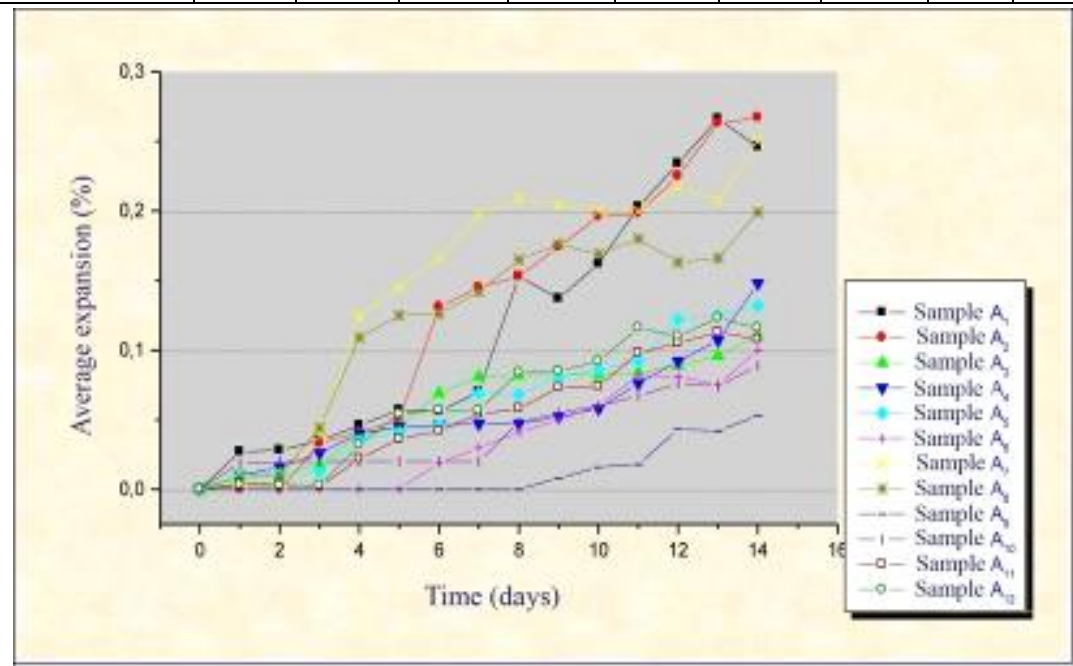

Figure 6 - The average expansion of bars (produced with each sample of aggregate) during the accelerated tests

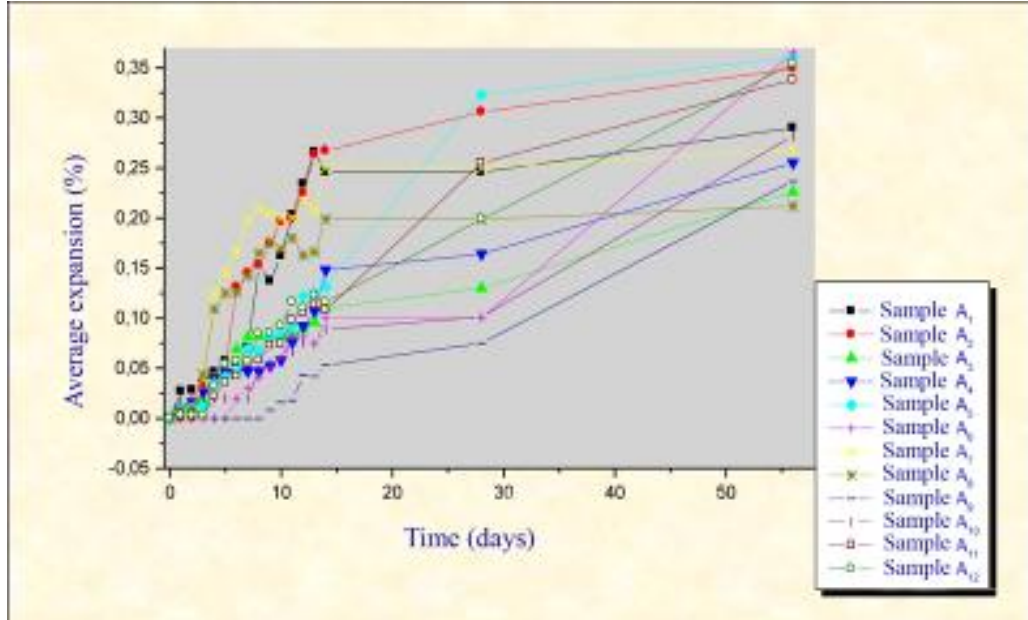

Figure 7 - The average expansion of bars (produced with each sample of aggregate) during the accelerated tests and the further treatment in $1 \mathrm{~N}$ alkaline solution, in environmental temperature 


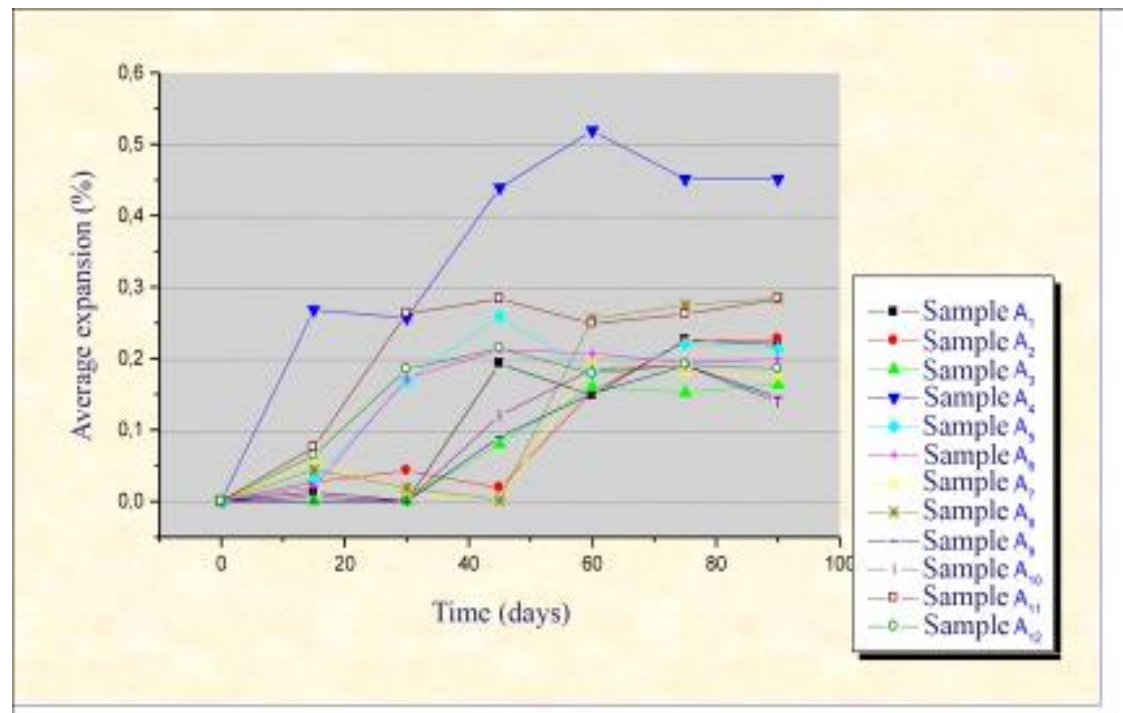

Figure 8 - The average expansion of bars (produced with each sample of aggregate) during the long-term (there months) tests

As it is shown in the Table 1 , all the samples contain some chert which is an alkali-reactive mineral. Referring to the recommendations of scientific literature, if the content of chert is over $0.5 \%$, the aggregate may be reactive and therefore must be tested further for its alkali-silica reactivity according to the method of continuity of tests.

From the Figure 6 it is evident that, after 14 days of exposure to the sodium hydroxide $1 \mathrm{~N}$ solution at $80^{\circ} \mathrm{C}$, the expansions of the mortar bars prepared with aggregate samples $A_{1}, A_{2}, A_{7}$ and $A_{8}$ (respectively $0.246,0.267,0.250$ and $0.199 \%$ ) exceed the limit of $0.2 \%$. Thus, these aggregates are considered to be reactive (according to UNI 8520-22) [2, 3].

The map pattern cracking, which is typical for ASR, is easily seen on the surfaces of these treated bars.

The expansions of the bars prepared with aggregate samples $A_{3}, A_{4}, A_{5}, A_{6}, A_{11}$ and $A_{12}$, after the accelerated tests, were from 0.1 to $0.2 \%$ (the uncertainty zone). The expansions corresponding to the bars prepared with aggregate samples $A_{9}$ and $\mathrm{A}_{10}$, after the accelerated tests, were below $0.1 \%$ (respectively 0.053 and $0.089 \%$ ).

Here we noticed that, in the first two days, the expansions of bars prepared by all samples were nearly the same; after that the bars prepared with aggregate samples which have resulted as reactive expanded more than the others. The daily experimental values of expansions of bars prepared with all samples were regressed to sigmoidal graphics. The statistical evaluation of graphics indicated a good accordance of graphics to experimental values.

In addition, we observed that, the degree of expansions in the accelerated tests is not in direct proportion to the quantity of alkali-active material in aggregates.

After the accelerated tests, we left the bars in the same $1 \mathrm{~N}$ alkaline solution but in room temperature and we measured their linear changes. As it is seen from the Figure 7, they continued to expand. This behavior of the mortar prepared by alkali-active aggregate has been noticed even by some authors in their experimental studies described in literature. The ASR gels, formed under the hard aggressive conditions in accelerated tests $\left(80^{\circ} \mathrm{C}\right.$ and high alkaline environment), continue to absorb water and to swell, even in room temperature.

The results taken from the long-term tests and especially the final expansions after three months (higher than the limit of $0.08 \%$ ), brought out that all the tested samples of Erzeni riverbed aggregates are potentially alkali-active.

The expansions of mortar bars prepared with the aggregate samples and cured in accelerated and long-term tests conditions are compared with the expansions of the respective mortar bars hardened in natural conditions (in distillated water at room temperature). The compression and flexure strengths, as well as the water absorption and the change of mechanical strengths after 16 freezethaw cycles for all mortar bars are measured, too. This is done in order to evaluate the influence of the test conditions in physico-mechanical performance of hardened mortars prepared with the aggregate samples. The respective results are shown in the Table 2.

From the Table 2 we notice that the flexure strengths, compared with compressive ones, are more sensible towards the tests conditions. 
Table 2 - Some physico-mecanical characteristics of mortar bars treated in natural conditions, in alkaline environment of accelerated tests and in long-term (three months tests)

\begin{tabular}{|c|c|c|c|c|c|c|c|c|c|}
\hline \multirow{2}{*}{$\begin{array}{c}\text { Mortar } \\
\text { bars } \\
\text { prepared } \\
\text { with } \\
\text { aggregate } \\
\text { sample }\end{array}$} & \multirow[b]{2}{*}{$\begin{array}{l}\text { Flexure } \\
\text { strength, } S_{f} \\
(\mathrm{Mpa})\end{array}$} & \multirow[b]{2}{*}{$\begin{array}{l}\text { Compression } \\
\text { strength, } \mathrm{S}_{\mathrm{c}} \\
(\mathrm{MPa})\end{array}$} & \multirow[b]{2}{*}{$\begin{array}{c}\text { Water } \\
\text { absorption } \\
(\%)\end{array}$} & \multicolumn{2}{|c|}{ Expansion (\%) } & \multirow{2}{*}{$\begin{array}{c}\text { The } \\
\text { decrease } \\
(\%) \text { of } S_{c} \\
\text { compared } \\
\text { with } \mathrm{S}_{\mathrm{c}} \text { of } \\
\text { natural } \\
\text { hardened } \\
\text { mortars }\end{array}$} & \multirow{2}{*}{\begin{tabular}{|c|} 
The \\
decrease $(\%)$ \\
of $\mathrm{S}_{\mathrm{f}}$ \\
compared \\
with $\mathrm{S}_{\mathrm{f}}$ of \\
natural \\
hardened \\
mortars \\
\end{tabular}} & \multicolumn{2}{|c|}{ After 16 freeze-thaw cycles } \\
\hline & & & & $\begin{array}{c}\text { After } \\
\text { expansion } \\
\text { tests }\end{array}$ & $\begin{array}{c}\text { After } 42 \\
\text { days in } \\
1 \mathrm{~N} \\
\text { alkaline } \\
\text { solution }\end{array}$ & & & $\begin{array}{l}\text { Compression } \\
\text { strength, } \\
\mathrm{S}_{\mathrm{c}}(\mathrm{MPa})\end{array}$ & $\begin{array}{l}\text { The change } \\
\text { of } \\
\text { compression } \\
\text { strength (\%) }\end{array}$ \\
\hline \multicolumn{10}{|c|}{ After hardened in natural conditions } \\
\hline$A_{1}$ & 9.49 & 59.64 & 3.86 & - & - & - & - & 68.04 & +14.08 \\
\hline $\mathrm{A}_{2}$ & 9.35 & 60.05 & 3.92 & - & - & - & - & 65.94 & +9.81 \\
\hline$A_{3}$ & 8.79 & 58.56 & 3.65 & - & - & - & - & 61.54 & +5.09 \\
\hline $\mathrm{A}_{4}$ & 9.78 & 56.70 & 3.20 & - & - & - & - & 65.56 & +15.63 \\
\hline$A_{5}$ & 9.05 & 60.64 & 4.02 & - & - & - & - & 69.10 & +13.96 \\
\hline$A_{6}$ & 9.54 & 61.34 & 3.65 & - & - & - & - & 69.96 & +14.06 \\
\hline$A_{7}$ & 9.75 & 54.32 & 3.64 & - & - & - & - & 59.68 & +9.85 \\
\hline$A_{8}$ & 8.01 & 56.37 & 3.79 & - & - & - & - & 63.87 & +13.32 \\
\hline$A_{9}$ & 9.45 & 57.42 & 3.52 & - & - & - & - & 61.20 & +6.6 \\
\hline$A_{10}$ & 9.78 & 55.98 & 3.04 & - & - & - & - & 64.42 & +15.08 \\
\hline$A_{11}$ & 10.00 & 53.94 & 3.46 & - & - & - & - & 61.38 & +13.80 \\
\hline$A_{12}$ & 8.45 & 61.23 & 3.75 & - & - & - & - & 66.28 & +8.25 \\
\hline \multicolumn{10}{|c|}{ After accelerated expansion tests and 42 days of treatment in $1 \mathrm{~N}$ alkaline solution, in room temperature } \\
\hline$A_{1}$ & 9.26 & 54.76 & 1.70 & 0.246 & 0.290 & -8.18 & -2.42 & 53.68 & -1.96 \\
\hline $\mathrm{A}_{2}$ & 6.87 & 50.38 & 1.20 & 0.267 & 0.340 & -16.10 & -26.55 & 48.87 & -2.99 \\
\hline$A_{3}$ & 8.52 & 54.45 & 1.91 & 0.110 & 0.226 & -7.04 & -3.07 & 54.19 & -0.47 \\
\hline $\mathrm{A}_{4}$ & 9.146 & 52.67 & 1.95 & 0.148 & 0.225 & -7.11 & -6.58 & 52.53 & -0.25 \\
\hline$A_{5}$ & 7.81 & 53.20 & 1.40 & 0.132 & 0.361 & -12.26 & $\begin{array}{l}-13.69 \\
\end{array}$ & 51.61 & -2.98 \\
\hline$A_{6}$ & 7.45 & 52.83 & 1.41 & 0.100 & 0.365 & -13.88 & -21.87 & 51.06 & -3.35 \\
\hline$A_{7}$ & 9.52 & 51.72 & 1.97 & 0.250 & 0.268 & -4.78 & -2.30 & 50.87 & -1.64 \\
\hline$A_{8}$ & 7,57 & 54.51 & 2.47 & 0.199 & 0.212 & -3.30 & -5.44 & 53.27 & -2.27 \\
\hline$A_{9}$ & 8.65 & 54.92 & 2.00 & 0.053 & 0.237 & -4.36 & -8.43 & 54.45 & -0.84 \\
\hline$A_{10}$ & 9.39 & 51.38 & 1.21 & 0.089 & 0.282 & -8.21 & -3.94 & 50.05 & -2.58 \\
\hline$A_{11}$ & 8.35 & 44.68 & 2.00 & 0.108 & 0.338 & -17.17 & -16.53 & 43.05 & -2.64 \\
\hline$A_{12}$ & 6.55 & 52.29 & 1.44 & 0.116 & 0.354 & -14.60 & -22.53 & 51.05 & -2.37 \\
\hline \multicolumn{10}{|c|}{ After long-term (there months) tests } \\
\hline$A_{1}$ & 9.33 & 57.32 & 1.63 & 0.219 & - & -3.88 & -1.63 & 56.90 & -0.73 \\
\hline$A_{2}$ & 9.03 & 59.95 & 2.11 & 0.227 & - & -0.16 & -3.44 & 59.62 & -0.55 \\
\hline$A_{3}$ & 8.77 & 58.40 & 1.90 & 0.164 & - & -0.26 & -0.20 & 58.41 & +0.02 \\
\hline $\mathrm{A}_{4}$ & 7,96 & 49.20 & 2.65 & 0.451 & - & -13.22 & -18.56 & 48.80 & -0.68 \\
\hline$A_{5}$ & 8.55 & 57.97 & 2.33 & 0.213 & - & -4.40 & -5.51 & 57.94 & -0.04 \\
\hline$A_{6}$ & 9.29 & 61.08 & 2.31 & 0.199 & - & -0.41 & -2.56 & 61.05 & -0.05 \\
\hline$A_{7}$ & 9.52 & 53.99 & 2.16 & 0.173 & - & -0.6 & -2.39 & 53.90 & -0.15 \\
\hline$A_{8}$ & 7.10 & 52.34 & 2.16 & 0.284 & - & -7.14 & -11.34 & 52.05 & -0.54 \\
\hline$A_{9}$ & 8.74 & 57.33 & 2.90 & 0.146 & - & -0.14 & -7.55 & 57.27 & -0.10 \\
\hline$A_{10}$ & 9.31 & 55.86 & 2.40 & 0.139 & - & -0.20 & -4.78 & 55.70 & -0.28 \\
\hline$A_{11}$ & 8.10 & 48.99 & 2.93 & 0.283 & - & -9.16 & -19.00 & 48.63 & -0.72 \\
\hline$A_{12}$ & 7.53 & 59.35 & 1.86 & 0.186 & - & -3.07 & -10.78 & 58.35 & 0 \\
\hline
\end{tabular}

According to literature in both types of tests (accelerated and long term) the reaction products formed are the alkali-silica gels; which have the same composition because their formation mechanisms are the same but the difference exists at the rate of alkali-silica reaction and the amount of gel produced. 
The results taken from our experiments also show that the decreases of the mechanical strengths of the mortar bars after the accelerated tests (compared with those of bars hardened in natural conditions) are higher than the decreases of the mechanical strengths after the long term tests (compared with those of bars hardened in natural conditions). This leads to the conclusion that with the increase of severity of test conditions increases the scale of deterioration of the physicomechanical characteristics of the mortar samples.

This tendency is verified even by the results of the freeze-thaw tests.

Meanwhile the results water absorption shown in table above indicate a different tendency: the water absorption of mortar samples decreases with the increase of the test severity. Thus, the water absorption of mortar samples, which passed through the long term tests (mild condition test), is higher than of those hardened in natural conditions and lower than the water absorption of those which passed through the accelerated tests condition (severe test).

Since the water absorption of a porous material is not the same as the porosity, in our case the results of water absorption tests are explained with the filling of the pores and channels inside the treated mortar bars with gelatinous reaction product, already saturated with water, resulting in lower water absorption values. The results of water absorption experiment led us to think that ASR products are present in treated concrete samples and that they are proportionally developed with the increase of severity of the test conditions, that means with the increase of simulated aging.

The results of the physico-mechanical tests, being in line with the water absorption indicators and with verified expansions of treated mortar samples give reason to conclude that the tested aggregates are potentially alkali silica active.

\section{Complexities of alkali-silica reaction (ASR) manifestation on concretes produced with Erzeni riverbed aggregates}

The evaluation of the possibility of manifestation of ASR phenomenon is somewhat complicated by the fact that sometimes the use of accelerated test to determinate the potential alkali-silica reactivity of concrete aggregates, can yield misleading results and inappropriate approval of certain reactive aggregates to be used in concrete production, even though in practice (in concrete structures) and in long-term tests, they perform as alkali reactive aggregate. This is the case of aggregates containing more than $2 \%$ of reactive constituents in the form of porous chert, flint or chalcedony. These aggregates exhibit the so-called "pessimum effect" in accelerated mortar bar tests.
According to researches and world experience, in this case there is a specific content of reactive material in aggregate, which in accelerated tests gives a maximum expansion or a peak. This quantity is called "negative content" (pessimum content) and indicates the worst possible condition. The reason for "the pessimum content" of aggregate in the standard accelerated tests is found to be in the mechanism of reaction development where for a certain content of alkalis, the expansion of mortar bars is increased as the content of reactive aggregate is increased up to a point "negative content", beyond which there are no more available alkalis to form expansive gel. At higher contents of active aggregate, the amount of alkalis become so low or dilute in mortar that occur just a slight or not at all expansion.

It is said, that in this case the concrete has reactive "buffer" silica. If at a further time, some available alkalis from outside sources (e.g. antifreeze salts, ground, etc.) are introduced in the concrete pore solution, then the excessive active silica can undergone ASR and can produce enough gel which with the water absorption may swell and in continuity cause the damage of concrete.

The other grave problem is that the dilution or augmentation of such aggregates with other nonreactive aggregates to avoid their pessimum proportion must not be used to control ASR expansion without thorough testing to identify nonexpansion aggregate combinations.

From the results of tests on Alkali-Silica reactivity of Erzeni riverbed aggregates carried out according to the Italian Standard UNI 8520-22 and shown in the paragraph above, one of the aggregate samples ( $A_{9}$, taken near Ndroq village) contained $3 \%$ of active mineral chert (this quantity is higher than in other tested aggregate samples). Nevertheless, the average expansion after the accelerated test was $0.053 \%$ (under the limit value of $0.1 \%$ ). So, according to the Standard UNI 852022 , this aggregate might be considered inactive and appropriate to be used in concrete and mortar production.

But, the results of the long-term tests (the expansion above $0.08 \%$ after three months of treatment of mortars bars in distillated water, in $38^{\circ} \mathrm{C}$ ) confirmed that all the aggregate samples, included even $A_{9}$, were alkali-reactive.

Based on the respective literature, the results taken with the mortars prepared with the Erzeni riverbed aggregate sample with $3 \%$ chert, prompted us to carry out some further tests to prove if this sample displayed "negative content".

For this purpose, in the mixture of mortar bars besides Erzeni riverbed aggregate sample $\left(A_{g}\right)$ we used as additive aggregate a limestone aggregate sample taken from a quarry near lba village on the road Tirana - Elbasan. 
From chemical analyses, the total silica content of this limestone sample resulted $0.28 \%$ (on mass). From petrographic examination and accelerated test of mortar bars, the limestone aggregate sample resulted non-reactive.

Both aggregate samples (reactive aggregate $A_{9}$ and non-reactive limestone one), were ground and their granulometric content was corrected according to the requirements of Standard UNI 8520 22.

After homogenization the reactive aggregate $A_{9}$ was used for mortar bars production on the ratios:
$0(\mathrm{G}), 25(\mathrm{~A}), 50(\mathrm{~B}), 70(\mathrm{C}), 80(\mathrm{D}), 90(\mathrm{E})$, and $100 \%\left(A_{9}\right)$ of the total weight of the filler.

These ratios corresponded to the respective amounts of: $0,0.75,1.5,2.1,2.4,2.7$, and $3 \%$ of reactive constituent chert in the mixed aggregate.

The mortar bars were tested according to accelerated test.

Below are shown the results of accelerated test for mortar bars prepared with various amount of reactive aggregate.

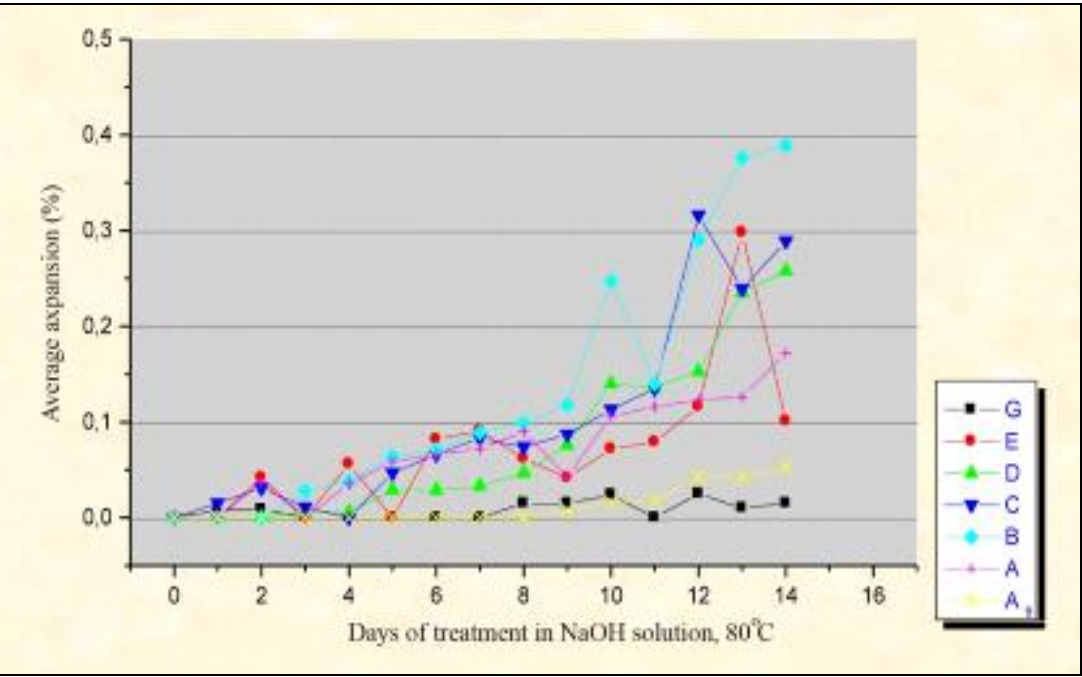

Figure 9 - The average expansion of mortar bars (produced with mixed aggregate) during the accelerated tests

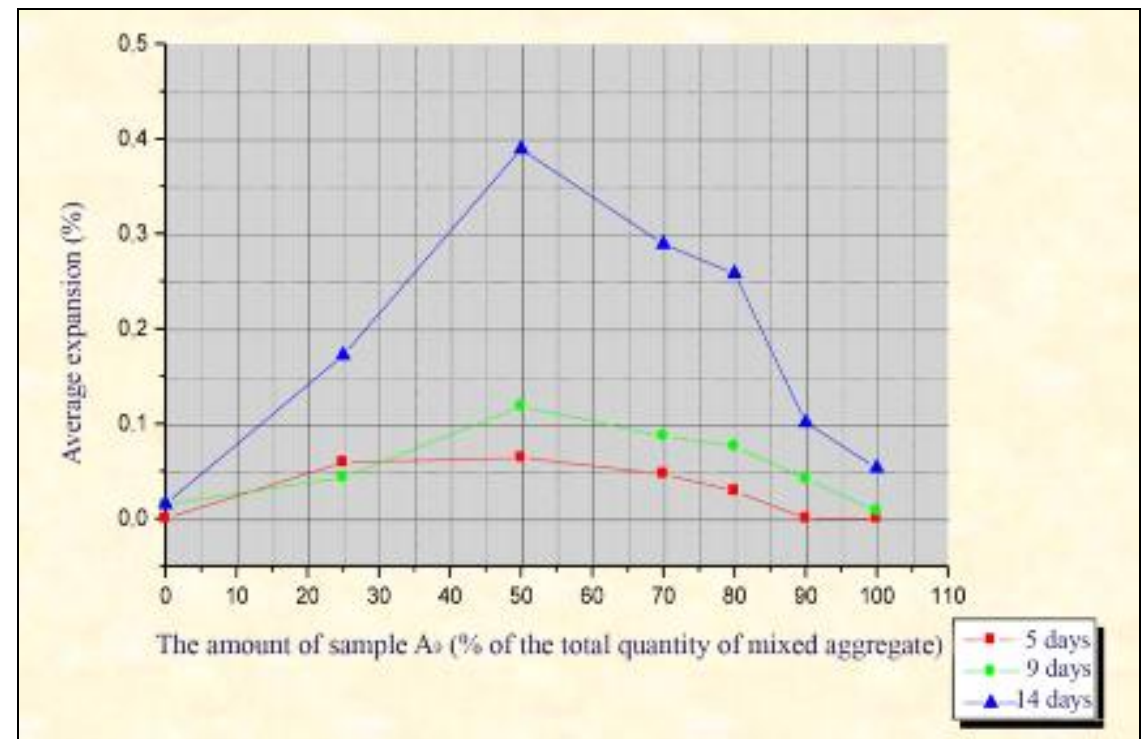

Figure 10 - The final expansion of the mortar bars as function of reactive aggregate content in mixed filler

It is evident that after the accelerated test, the expansions of all mortar bars prepared with mixed aggregates (reactive aggregate $\mathrm{A}_{9}$ and limestone aggregate) were higher than expansions of mortar bars prepared by reactive aggregate or limestone aggregate used individually.
The final expansion of mortar bars, where the reactive aggregate $A_{9}$ is used in the amounts $25 \%$ and $90 \%$, lied at the uncertainty zone (0.1-0.2\%).

The final expansion of mortar bars, where the reactive aggregate $A_{9}$ is used in the amounts 50 , 70 and $80 \%$, was above $(0.2 \%)$. 
From the Figure 10, where is shown the final expansion of the mortar bars as function of reactive aggregate content in mixed filler, it is seen that for reactive aggregate $A_{9}$ and its studied ratios with limestone aggregate, exists a "negative content" in relation to alkali-silica reactivity. This content belongs to the ratio 50:50 (reactive aggregate: nonreactive limestone aggregate), which corresponds to the content of $1.5 \%$ of reactive mineral chert. The lower critical limit belongs to the amount round $30 \%$ reactive aggregate $(0.9 \%$ chert $)$ and the upper critical limit belongs to the amount round $85 \%$ reactive aggregate $(2.55 \%$ chert).

From the results of these experiments we came to the conclusion that the "pessimum effect" happened while treating the aggregate sample $A_{9}$ with accelerated test procedure.

In this case, due to velocity of reaction caused by severity conditions of the accelerated test, in mortar bars prepared by $100 \%$ reactive aggregate
$A_{9}$ (3\% chert), "an outside zone of reaction" could have been formed. The outside zone reaction forms a barrier which confined the further entrance of alkalis from $\mathrm{NaOH}$ solution and it seems to be the determinant (critical) factor in accelerated test. So, the ASR activity at the outside zone of aggregate, results in formation of a gel type less ropy than in mild testing conditions. This gel blocks the voids of cement paste and inhibits the further entrance of $\mathrm{NaOH}$ into the interior part of mortar bars, thus the reaction occurrence there. The "negative content" indicates the latent alkali-silica reactivity of aggregate.

In order to have a full picture of the phenomenon, we made the physico-mechanical tests of the mortar bar samples produced with mixed aggregates before and after the accelerated tests.

The respective results are shown in Figures 11 and 12.

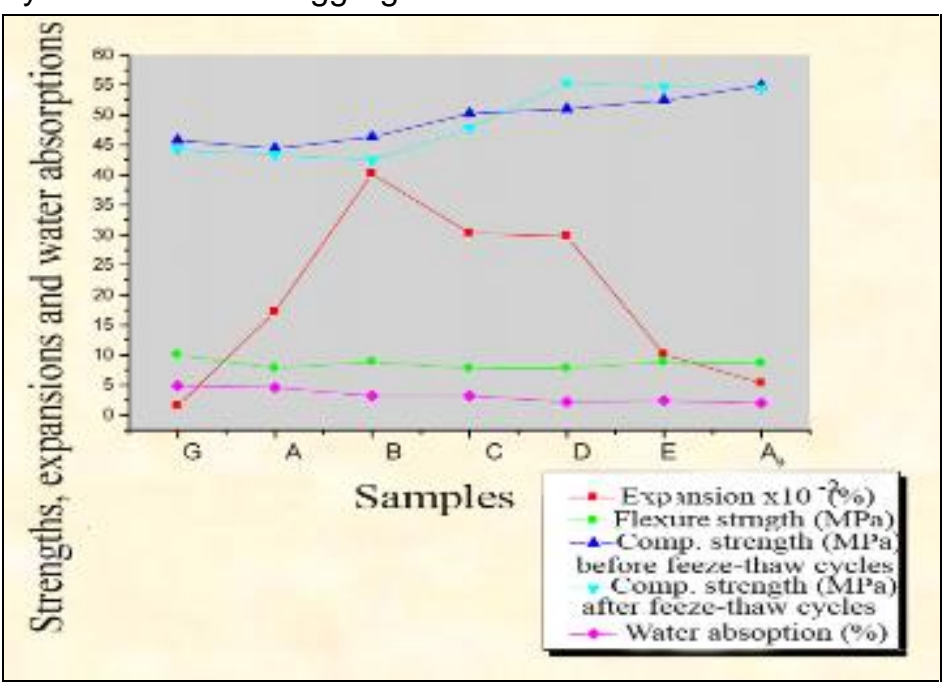

Figure 11 - Some physico-mechanical characteristics of mortar bars with mixed aggregates after the accelerated tests

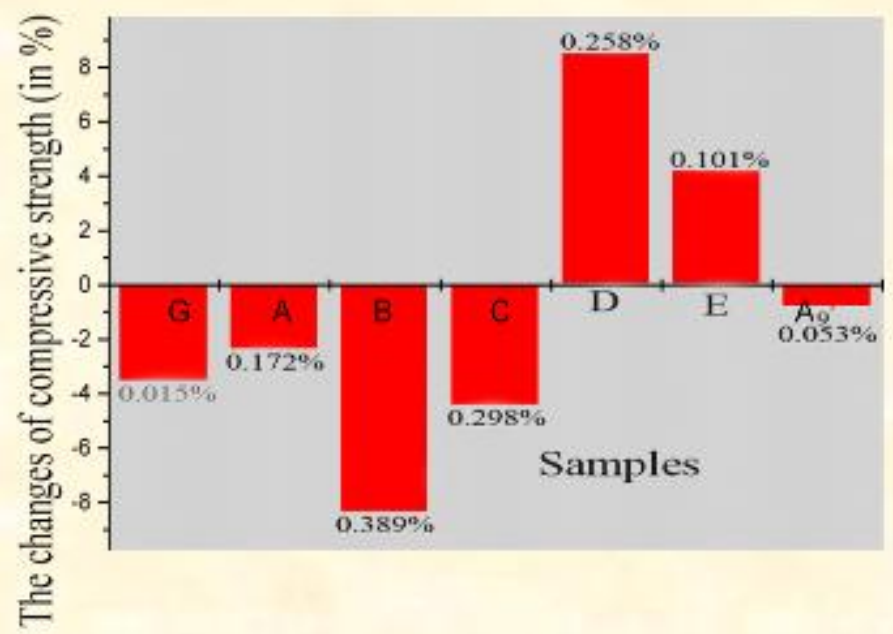

Figure 12 - The changes of compressive strengths of mortar bars with mixed aggregates after freeze-thaw cycles (The expansions, in \%, after accelerated tests are shown for each specific mixed aggregate) 
It must be noted that when mixed aggregates are used as mortar fillers, in addition to the AlkaliSilica Reaction occurrence and its consequences, the different physico-mechanical characteristics between the two types of aggregates (siliceous and limestone ones) have an importance influence to the characteristics of hardened mortars. Here are some indicators:

- compression strength (comp. strength limestone $<$ comp. strength siliceous aggregate);

- water absoption (water absoption limestone $_{\text {- water }}$ absoption $_{\text {siliceous aggregate); }}$;

- the decrease of compression strength after freeze-thaw cycles (decrease of comp. strength $_{\text {limestone }}>$ decrease of comp. strength $\left.{ }_{\text {siliceous agregate }}\right)$; etc.

So, checking from mortar bars with sample $G$ to those with $A_{9}$ it is seen that; there is not any regularity for flexure strengths, the compressive strengths are increased from $G$ to $A_{9}$, the water absorption is decreased from $G$ to $A_{9}$, the expansion curve shows a peak for $B$ ("pessimum content" of $A_{9}$ aggregate sample), the compressive strengths after freeze-thaw tests are at minimum values for mortar bars $B$.

Finally, after analyzing the results taken from the continuity tests and other tests described above, we conclude that:

- The examined aggregate samples of Erzeni Riverbed are potentially alkali-reactive.

- Based on the fact that from $92 \%$ of the examined cases are taken results in line with the Standard UNI 8520-22 recommendations and the world experience, we consider that the used method for the potentially alkali-silica reactivity determination of aggregate samples is the right one and permits us to draw correct conclusions and to give useful recommendations.

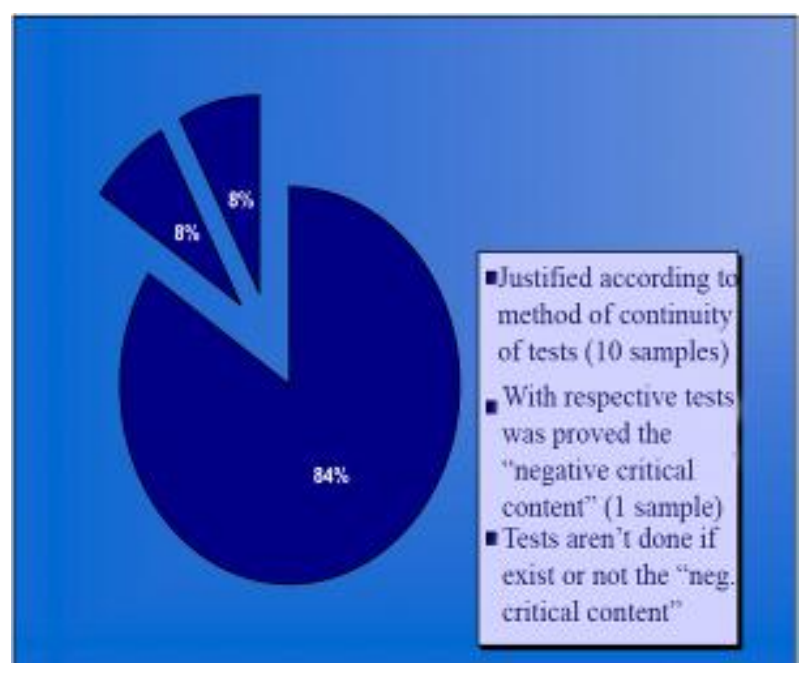

- The fact that for one of aggregate samples, ( $8 \%$ of the examined cases), the result of the accelerated test conflicts the result of the longterm test, does not show that the accelerated tests are ineffective, but the fact that the acelerated tests have to follow the petrographic examination and must be used carefully.

- The results taken from our experiments confirmed the recommendations given in the respective literature, for using the method of continuity of tests under a thorough cycle (petrographic examination, accelerated tests and long-term tests 3 or 6 months long) in cases when the aggregate to be tested contains more than $2 \%$ of reactive constituents in the form of porous chert, flint or chalcedony.

- The expansion of the mortar bars prepared from alkali-silica aggregates is influenced by the chert presence. But, there isn't a direct relation between the amount of chert in aggregate and the expansion value. Thus, expansion isn't influenced only by the chert presence in aggregate, but rather by the chert amount above $2 \%$, the chert composition and its specific characteristics in each aggregate, other siliceous constituents in aggregate, as well as other factors that may have effect on the solubility of active silica forms.

6. Microscopic observations in relation to the possibility of the of Alkali-Silica Reaction manifestation in concrete prepared by Erzeni Riverbed aggregates

In addition to aggregate analyses, the microscopic examination of the concrete helps to confirm that a concrete produced with aggregates containing silica could be vulnerable towards ASR phenomenon.

A small magnification of a smoothed concrete surface shows the rings of reaction around particles of reactive aggregate. In a thin section of the concrete sample, signs of ASR include cracks originating from the particles of the reactive aggregate, discolored zones around the aggregate granules and the filling of the cracking gaps with gel.

To check if the ASR related signs were obvious, besides the recommendations of the Standard UNI 8520-22, 1999, several parts cut from the mortar bars treated in the accelerated tests were examined using stereomicroscope (10X). These parts were taken in inner central zones as well as $4 \mathrm{~mm}$ from the outside surface of these bars. From the stereoscopic microscope observations (10X) of the treated mortar bars it isn't seen any visible cracks.

Polished thin sections $(0.1$ to $0.2 \mathrm{~mm})$ of all mortar samples, that were treated in expansion tests, are examined on polarized-light microscope and the main raw materials of mortars (aggregate and cement paste as binding material) are analyzed. The photographs are taken with digital camera on the microscope's screen. 

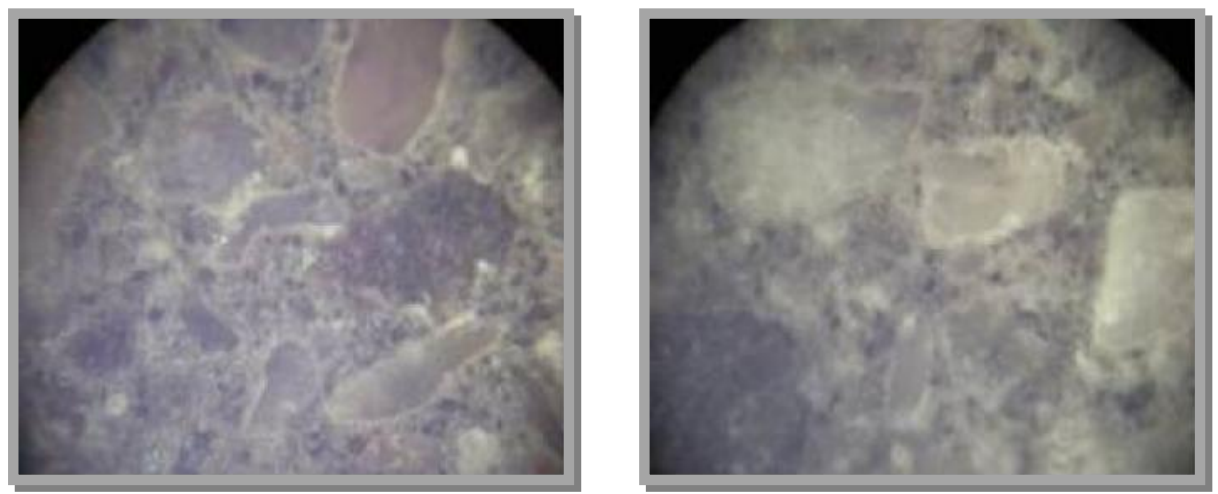

Figure 13 - View on stereoscopic microscope (10X) of a mortar bar prepared by aggregate sample $A_{2}$ after alkaline treatment (on the left - the surface part, on the right - the interior one)

Also, the interior of treated mortar bars are examined by SEM to identify the presence of internal cracking and the mapping of elements within the reactive aggregate particles. For comparison reasons, photos of the microstructure of mortars hardened in natural environment are taken, too. The photos of microstructure are taken from the inner zones and the near outside surface of bars'

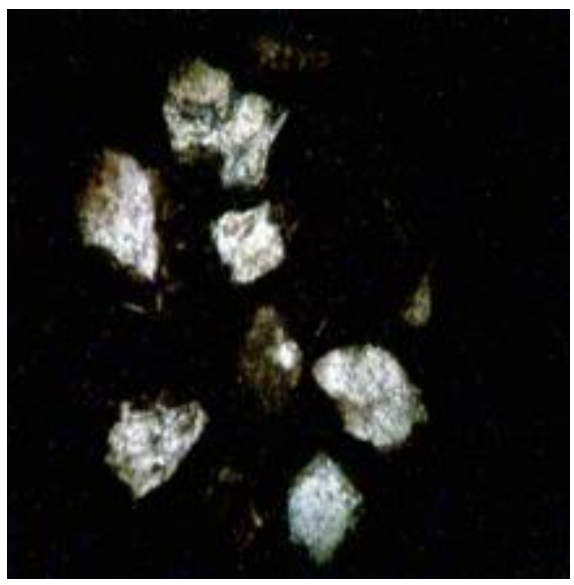

zones of the irregularly broken parts of bars as well as of the respective prepared polished surfaces of bars. Also some useful information is taken by XRay Elemental Map (EDX-microanalysis).

The main observed findings are shown here in the form of a group of photos only for the hardened mortars prepared by the Erzeni riverbed aggregate sample $A_{2}$.

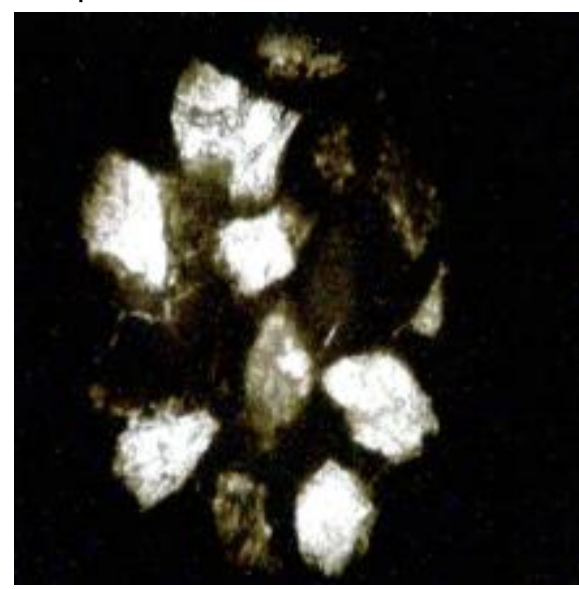

Figure 14 - Views of sandy granules from a thin section of mortar bar produced with aggregate of sample $A_{2}$ hardened in natural environment, taken with polarized-light microscope (100X), with and without analyzer (leftright). The background is dark because it is photographed with digital camera from the screen of the microscope

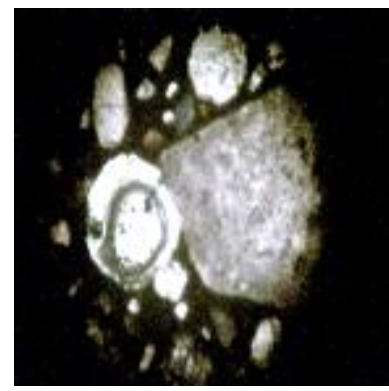

a)

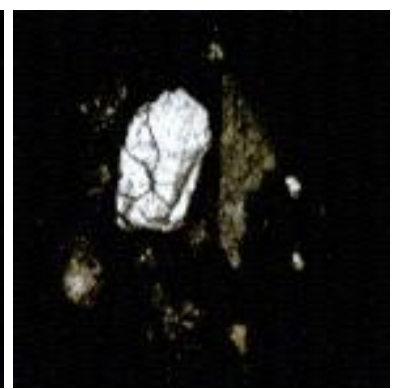

b)

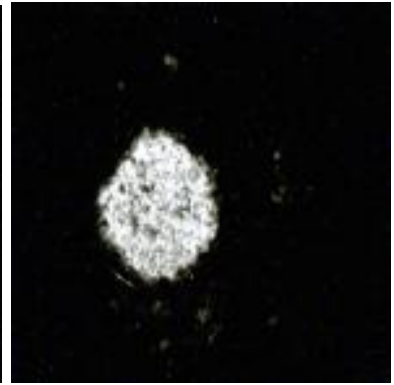

c)

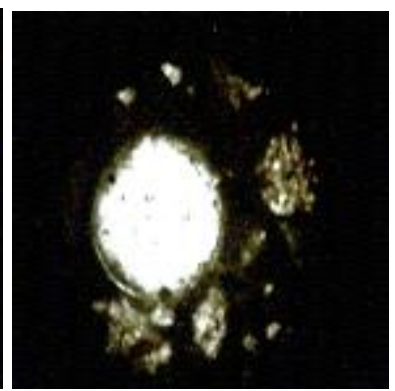

d)

Figure 15 - Views of sandy granules from thin sections of mortar bar produced with aggregate of sample $A_{2}$ hardened in alkaline solution, taken with polarized-light microscope (100X) with analyzer except for the last one 


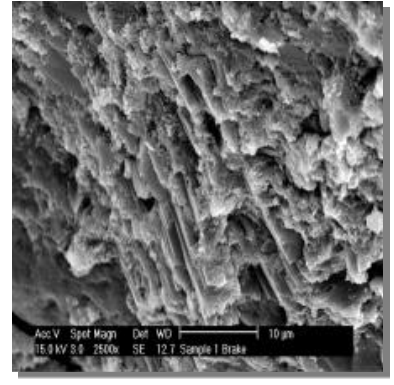

a)

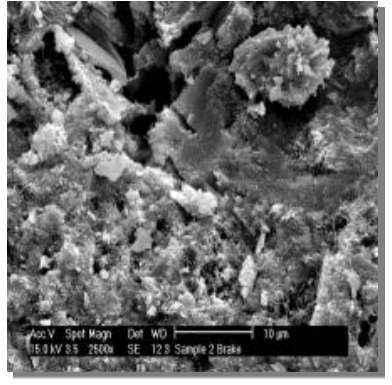

b)

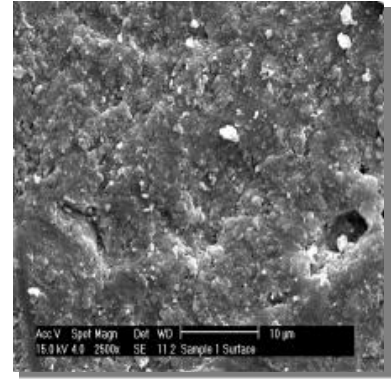

c)

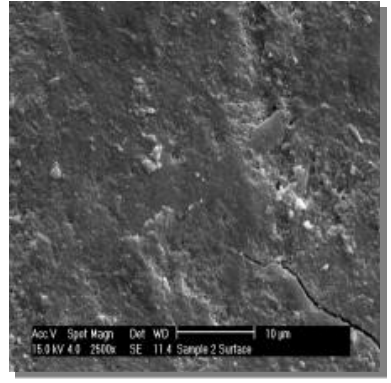

d)

Figure 16 - SEM photo of the surface of breaking $(a, b)$ and polished surface $(c, d)$ of the mortar bar produced with aggregate of sample $A_{2}$ hardened in natural environment $(a, c)$ and in alkaline solution (b,d)
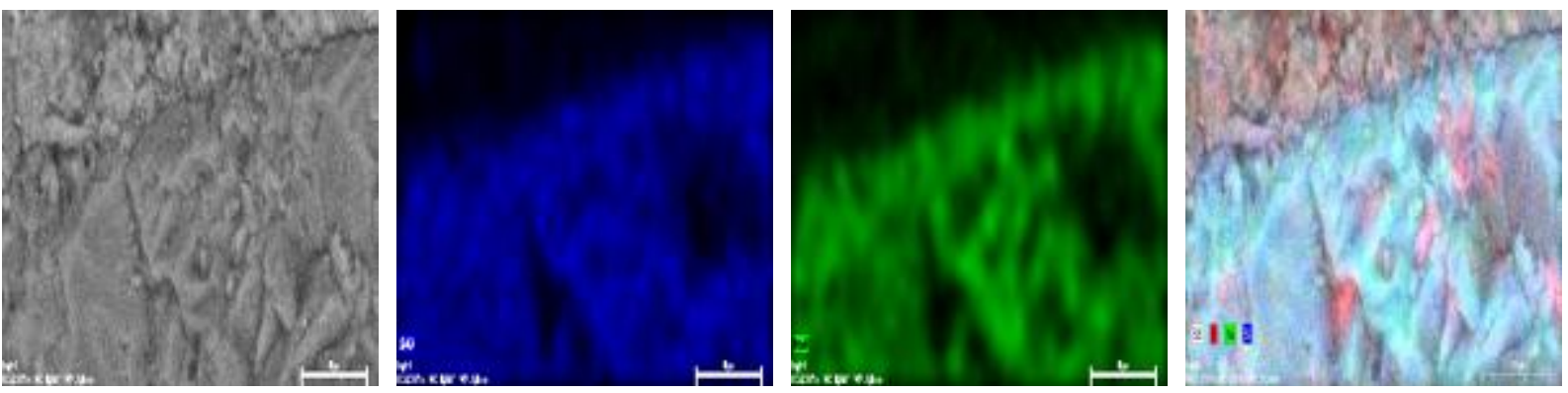

Figure 17 - EDX photo where we can trace, at a magnification of $3116 \mathrm{X}$, the content of elements Si, $\mathrm{Na}$ and $K$ within and around of a silica sandy granule in the mortar bar produced with sample $A_{2}$ aggregate, hardened in alkaline solution

From the observation, using optic microscope, of the thin sections prepared from one of mortars (sample $A_{2}$ ), hardened in $\mathrm{NaOH} 1 \mathrm{~N}$ solution at the temperature $80^{\circ} \mathrm{C}$, was noticed the presence of silica particles that had reacted with binding material.

In the photos (Figure 14 and 15) of this sample, an interposition of the binding material (cement) with the silica particles of the aggregate was noticed, as well as discolored rings around aggregates and here and there cracks of silica granules. All these are characteristic signs of Reaction AlkaliSilica.

Results obtained from accelerated tests are confirmed by the observation using SEM.

Comparing the SEM microstructure photos (Figure16 a, b) of the mortar bar's surface of breaking, it is obvious the distinction between the microstructure of the cement paste of concrete hardened in natural environment and of that hardened in alkali environment where ASR caused an expansion.

In the case of bars hardened in natural environment there is a more homogenous microstructure of cement paste compared with prisms hardened in alkali environment.
Comparing the SEM microstructure photos of the polished surfaces of mortar bars produced with the same aggregate sample $A_{2}$, but hardened in different environments, it is noticed that cracks are present only in the sample hardened in alkaline environment.

The accelerated tests in presence of alkalis have simulated the aging of the mortar bars and caused their expansion and consequently the cracks that deteriorate the appearance and functional characteristics of the concrete.

From Elemental Distribution Map (distribution of elements, EDX), Figure 17, it is noticed that where the concentration of silica is bigger (in the silica granule), there is a bigger accumulation of the sodium ions compared with the cement paste around it. This confirms the conclusion of the presence of the alkali-silica gel formed as product of ASR.

Based on the above experiments and observations, we confirm that the aggregates of river Erzen are sensitive towards alkali environment of the mortars and concretes and may influence negatively in the characteristics and life expectancy of the mortars and concretes produced with them if no proper intervention is made in mix design $[2,16]$. 
7. Influence of the concrete mix design on AlkaliSilica Reactivity of Erzeni Riverbed aggregates

The purpose of this research has been the determination of the influence in the concrete expansion caused by ASR of these factors:

- Water to cementing material ratio in the mortar mix design $\left(z_{1}\right)$.

- Concentration of $\mathrm{NaOH}$ solution in accelerated expansion tests $\left(z_{2}\right)$.

- Quantity of copper slag used for partial substitution of Portland cement in the mortar mixture design $\left(z_{3}\right)$.

- Aggregate to cementing material ratio in the mortar mix design $\left(z_{4}\right)$.

The other factors that are considered to have minor influence in the concrete expansion caused by ASR phenomenon are kept, to a practical extend, constant in all experiments performed.
An attempt is made to express mathematically the relationship of the concrete expansion caused by $\operatorname{ASR}(y)$ and the over mentioned four main factors $\left(z_{1}, z_{2}, z_{3}\right.$ and $\left.z_{4}\right)$.

Based on the theoretical and practical considerations, the level zero $z_{\mathrm{j}}^{0}$ and the step of variation $\Delta z_{j}$ were set up as well as the codified variables for every factor:

$$
\begin{array}{ll}
x_{1}=\frac{z_{1}-z_{1}^{o}}{\Delta z_{1}} ; & x_{2}=\frac{z_{2}-z_{2}^{o}}{\Delta z_{2}} ; \\
x_{3}=\frac{z_{3}-z_{3}^{o}}{\Delta z_{3}} ; & x_{4}=\frac{z_{4}-z_{4}^{o}}{\Delta z_{4}}
\end{array}
$$

The zone of variation of the participant factors in the experiment, the level zero $z_{j}^{0}$ and the step variation $\Delta \mathrm{z}_{\mathrm{j}}$ set up for each factor are shown in the Table 3.

Table 3 - Level zero and the step variation values for each factor

\begin{tabular}{|c|c|c|c|c|}
\hline & $\begin{array}{c}\text { Water to cement } \\
\text { ratio, }\left(z_{1}\right)\end{array}$ & $\begin{array}{c}\text { Concentration of } \mathrm{NaOH} \\
\text { solution, } \mathrm{M}\left(z_{2}\right)\end{array}$ & $\begin{array}{c}\text { Content of copper slag, } \\
\text { in } \%,\left(z_{3}\right)\end{array}$ & $\begin{array}{c}\text { Aggregate to cementing } \\
\text { material ratio, }\left(z_{4}\right)\end{array}$ \\
\hline$z_{\mathrm{j}}^{\circ}$ & 0.47 & 1 & 20 & 2.25 \\
\hline$\Delta z_{\mathrm{j}}$ & 0.03 & 0.2 & 10 & 0.4 \\
+1 & 0.50 & 1.2 & 30 & 2.65 \\
\hline-1 & 0.44 & 0.8 & 10 & 1.85 \\
+2 & 0.53 & 1.4 & 40 & 3.05 \\
\hline-2 & 0.41 & 0.6 & 0 & 1.45 \\
\hline
\end{tabular}

Therefore the expansion $y$ will be function of codified variables $y=f\left(x_{1}, x_{2}, x_{3}, x_{4}\right)$.

The regress equation has been quested in the form of second degree polynomial.

$$
y=a_{o}+\sum_{j=1}^{4} a_{j} x_{j}+\sum_{j<j} a_{i j} x_{i} x_{j}+\sum_{j=1}^{4} a_{j} x_{j}^{2}
$$

where: $j=1,2,3$ or 4 .

Based on the method of experiment planning for uniform rotational plane of second order with 4 factors, a set of 31 experiments are arranged.

The raw materials used in this study include fine reactive aggregate, Portland cement, copper slag and distilled water.

- The fine aggregate is prepared from riverbed Erzen which, with round $2 \%$ chert in its mineralogical content is a potential reactive aggregate as evaluated according to UNI 852022 tests [2].

- As cementing material is used clinker with $5 \%$ gypsum produced in Fushë- Kruja Cement Factory, Albania. The content of $\mathrm{Na}_{2} \mathrm{O}_{\text {eq }}$ in cement was $1.22 \%$. The cement was ground to specific surface $3887 \mathrm{~cm}^{2} / \mathrm{gr}$.

- The Copper slag, a waste of the Copper Production Plant in Laç, Albania, was ground at the same specific surface as Portland cement and used in various quantities for replacing of Portland cement.

Experiments planning guidelines are based on the experience and the literature of concrete production, aiming that the values given to each factor in each experiment were within the limits of the normal concrete production as well as around the values recommended by the Italian standard for the evaluation of the alkali-silica activity of the aggregates. The slag quantity range is based on the current use of the copper slag in cement production in Albania.

The values of all factors as well as their respective codified variables involved in each experiment are shown in Table 4.

The evaluation of the Alkali Silica Reactivity in each of 31 experiments is performed according to UNI 8520-22 testing method. 
Table 4 - Mix design of mortar bars and their expansions (measured and calculated) after the accelerating tests in $\mathrm{NaOH}$ solution for all 31 experiments performed

\begin{tabular}{|c|c|c|c|c|c|c|c|c|c|c|}
\hline \multirow[t]{2}{*}{$\begin{array}{c}\text { Test } \\
\text { Number }\end{array}$} & \multicolumn{2}{|c|}{$\begin{array}{l}\text { Water to } \\
\text { cement ratio }\end{array}$} & \multicolumn{2}{|c|}{$\begin{array}{l}\text { Concentration of } \\
\mathrm{NaOH} \text { solution } \\
\text { (M) }\end{array}$} & \multicolumn{2}{|c|}{$\begin{array}{c}\text { Content of } \\
\text { copper slag (\%) }\end{array}$} & \multicolumn{2}{|c|}{$\begin{array}{l}\text { Aggregate to } \\
\text { cementing } \\
\text { material ratio }\end{array}$} & \multirow{2}{*}{$\begin{array}{c}\text { Measured } \\
\text { expansion } \\
\%\end{array}$} & \multirow{2}{*}{$\begin{array}{c}\text { Calculated } \\
\text { expansion } \\
\%\end{array}$} \\
\hline & $z_{1}$ & $x_{1}$ & $z_{2}$ & $x_{2}$ & $z_{3}$ & $x_{3}$ & $z_{4}$ & $x_{4}$ & & \\
\hline 1 & 0.44 & -1 & 0.8 & -1 & 10 & -1 & 1.85 & -1 & 0,126 & 0,122 \\
\hline 2 & 0.50 & +1 & 0.8 & -1 & 10 & -1 & 1.85 & -1 & 0,152 & 0,155 \\
\hline 3 & 0.44 & -1 & 1.2 & +1 & 10 & -1 & 1.85 & -1 & 0,141 & 0,147 \\
\hline 4 & 0.50 & +1 & 1.2 & +1 & 10 & -1 & 1.85 & -1 & 0,177 & 0,179 \\
\hline 5 & 0.44 & -1 & 0.8 & -1 & 30 & +1 & 1.85 & -1 & 0,043 & 0,047 \\
\hline 6 & 0.50 & +1 & 0.8 & -1 & 30 & +1 & 1.85 & -1 & 0,080 & 0,080 \\
\hline 7 & 0.44 & -1 & 1.2 & +1 & 30 & +1 & 1.85 & -1 & 0,058 & 0,056 \\
\hline 8 & 0.50 & +1 & 1.2 & +1 & 30 & +1 & 1.85 & -1 & 0,090 & 0,089 \\
\hline 9 & 0.44 & -1 & 0.8 & -1 & 10 & -1 & 2.65 & +1 & 0,055 & 0,061 \\
\hline 10 & 0.50 & +1 & 0.8 & -1 & 10 & -1 & 2.65 & +1 & 0,066 & 0,071 \\
\hline 11 & 0.44 & -1 & 1.2 & +1 & 10 & -1 & 2.65 & +1 & 0,095 & 0,099 \\
\hline 12 & 0.50 & +1 & 1.2 & +1 & 10 & -1 & 2.65 & +1 & 0,109 & 0,109 \\
\hline 13 & 0.44 & -1 & 0.8 & -1 & 30 & +1 & 2.65 & +1 & 0,031 & 0,027 \\
\hline 14 & 0.50 & +1 & 0.8 & -1 & 30 & +1 & 2.65 & +1 & 0,033 & 0,037 \\
\hline 15 & 0.44 & -1 & 1.2 & +1 & 30 & +1 & 2.65 & +1 & 0,043 & 0,049 \\
\hline 16 & 0.50 & +1 & 1.2 & +1 & 30 & +1 & 2.65 & +1 & 0,057 & 0,06 \\
\hline 17 & 0.41 & -2 & 1 & 0 & 20 & 0 & 2.25 & 0 & 0,074 & 0,069 \\
\hline 18 & 0.53 & +2 & 1 & 0 & 20 & 0 & 2.25 & 0 & 0,117 & 0,112 \\
\hline 19 & 0.47 & 0 & 0.6 & -2 & 20 & 0 & 2.25 & 0 & 0,049 & 0,046 \\
\hline 20 & 0.47 & 0 & 1.4 & +2 & 20 & 0 & 2.25 & 0 & 0,099 & 0,093 \\
\hline 21 & 0.47 & 0 & 1 & 0 & 0 & -2 & 2.25 & 0 & 0,162 & 0,154 \\
\hline 22 & 0.47 & 0 & 1 & 0 & 40 & +2 & 2.25 & 0 & 0,031 & 0,029 \\
\hline 23 & 0.47 & 0 & 1 & 0 & 20 & 0 & 1.45 & -2 & 0,142 & 0,141 \\
\hline 24 & 0.47 & 0 & 1 & 0 & 20 & 0 & 3.05 & +2 & 0,060 & 0,051 \\
\hline 25 & 0.47 & 0 & 1 & 0 & 20 & 0 & 2.25 & 0 & 0,086 & 0,081 \\
\hline 26 & 0.47 & 0 & 1 & 0 & 20 & 0 & 2.25 & 0 & 0,076 & 0,081 \\
\hline 27 & 0.47 & 0 & 1 & 0 & 20 & 0 & 2.25 & 0 & 0,080 & 0,081 \\
\hline 28 & 0.47 & 0 & 1 & 0 & 20 & 0 & 2.25 & 0 & 0,087 & 0,081 \\
\hline 29 & 0.47 & 0 & 1 & 0 & 20 & 0 & 2.25 & 0 & 0,081 & 0,081 \\
\hline 30 & 0.47 & 0 & 1 & 0 & 20 & 0 & 2.25 & 0 & 0,081 & 0,081 \\
\hline 31 & 0.47 & 0 & 1 & 0 & 20 & 0 & 2.25 & 0 & 0,080 & 0,081 \\
\hline
\end{tabular}

With the measured expansion of mortar bars according to the experiment procedures, using the appropriate methods for uniform rotational plane of second order with 4 factors (Table 4 , penultimate column), as well as the regression and correlation analyses offered by software program MatLab, are computed correlation coefficients.

The regression function found in this way is:

$y=0.08157+0.01075 x_{1}+0.01183 x_{2}-0.03117 x_{3}-$ $-0.02258 x_{4}-0.00562 x_{1} x_{4}-0.00387 x_{2} x_{3}+$ $+0.00337 x_{2} x_{4}+0.01025 x_{3} x_{4}+0.00231 x_{1}^{2}$.

$-0.00306^{x_{2}^{2}}+0.00256^{x_{3}^{2}}+0.00369^{x_{4}^{2}}$
The calculated experiment error is $1.428 \mathrm{E}-5$ and the standard deviation is 0.00378 .

According to the regression equation, for every experiment the values of $y$ are calculated. These values are shown too, in the Table Nr. 4, in the ultimate column.

From the regress equation it is apparent that within the boundaries of this experiment, the expansion of mortar bars increases with:

- The increase of the water to cementing material ratio

- The increase of the concentration of $\mathrm{NaOH}$ solution in accelerated expansion tests (that is when the alkaline load in mortar is increased). 
- The decrease of the quantity of copper slag used for partial substitution of Portland cement.

- The decrease of the aggregate to cementing material ratio in the mortar.

The comparison of the absolute values of the coefficients in the regress equation clearly shows that the quantity of slag and the aggregate to cementing material ratio have the biggest influence in the amount of expansion, which means in the development of ASR.

The fact that some terms of the correlation between factors have a considerable value in the regress function signifies that the ASR phenomena and its manifestation is a complex process. The values of the coefficients show that the correlation between the quantities of slag with aggregate cementing material ratios have the biggest influence in the amount of expansion caused by the ASR.

To create a clearer idea on the influence and the correlation of the four studied factors, the relationship expressed by the above equation, can be represented graphically using the MatLab software program.

Since the function represents the dependence of ASR expansion on four factors, the threedimensional graphical representation of the function is possible by keeping constant the values of two factors and varying the values of the other two ones.

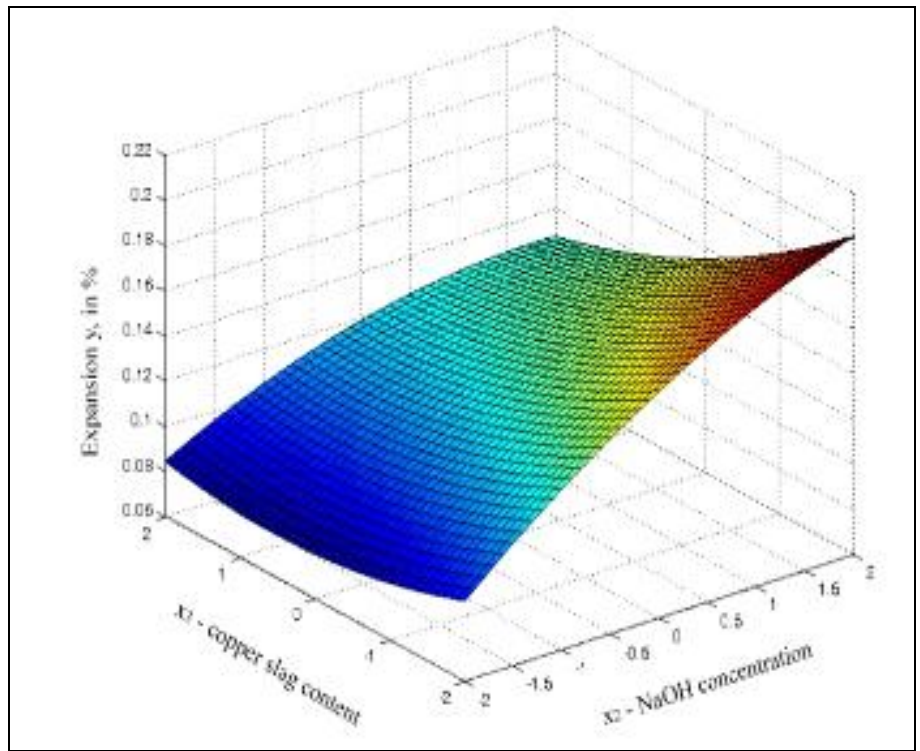

Figure 18 - ASR expansion $y$ as function of $x_{2}$ and $x_{3}\left(x_{1}=+1 ; x_{4}=+2\right)$

As an example, in the Figure 18 is shown the dependence of the expansion $y$ from slag quantity $x_{3}$ and $\mathrm{NaOH}$ concentration $x_{2}$, keeping constant the water to cement ratio $x_{1}$ and aggregate to cement ratio $x_{4}$. Such graphical displays can be generated in 6 combinations.

Reasoning from the three dimensional graphics, for a certain expansion that may be allowed in the concrete to be produced (depending by its use conditions), it is possible to generate two dimensional graphics which facilitate the choice of the due values of those variable factors.

Graphics generated in this way could serve producers to prepare the due mix receipts in order to avoid the risk of the ASR expansion and deterioration of the concretes and mortars [2,15,17 -19].

In order to prevent or mitigate the derogative and destructive phenomenon caused by the development of Alkali Silica Reaction in concretes and mortars produced with aggregates taken from the Erzeni riverbed, it is recommended to have a special attention to the mix design of concretes and mortars, especially for hydraulic concrete struc- tures and those to be used in moisture and water environment.

\section{REFERENCES}

[1] Marku J. - "The study on Alkali-Silica Potential Expansion of Active Aggregates in Concretes", Master of Science micro theses, University of Tirana, Albania, June 2003

[2] Marku J. - "Alkali-Silica Expansion Potentially of Erzeni Riverbed Aggregates and the Risk of Corrosion in Concretes produced with them", PhD theses, University of Tirana, Albania, November 2006

[3] UNI 8520-22 1999 - "Aggregati per confenzione di calcestruzzi. - Determinazione della potenziale reattività degli aggregati in prezenza di alkali”, UNI Via Battistotti Sassi, 11B 20133 Milano, Italia

[4] Marku J., Jana N. - "Study on Alkali-Silica Potential Expansion of Active Aggregates in Concretes", $3^{\text {rd }}$ International Symposium "Materials and their use", Network of Materials Science and Engineering University of Prishtina, TU Bergakademie Freiberg, Polytechnic Universityof Tirana, Prishtina, Kosovo, November 2003 
[5] Marku J. (2010) The incorporation of fly ash as suplementary cementing material in concrete, Zastita materijala 51 (3), 159-164

[6] Marku J., Jana N., Caja Sh. - "Potential Risk manifestation of Alkali-Silica Reactions in Concretes prepared by aggregates from different riverbeds in Albania", $4^{\text {th }}$ International Conference of the Chemical Societies of the South-East European Countries, Chemical Sciences in Changing Times: Visions, Challenges and Solutions, Belgrade, Serbia, July 2004

[7] Korpa A., Kota T., Spahiu E., Trettin R. (2013) An innovative approach for producing high volume fly ash blended cements that meet European standard requirements by employing a silicious coal fly ash exhibiting unusually high water demand and other peculiar properties, Zastita materijala 54 (4), 334340

[8] Marku J., Jana N. 2004. - "Study on alkali-silica potentially of some riverbed aggregates used for concrete production in Albania", Scientific Bulletin of University of Shkodra, No. 54, Albania

[9] Marku J., Jana N. - "The risk that menaces our concretes", Journal Monitor, Tirana, Albania, February 2005

[10] Prifti D., Prifti M., (2013) Tuffs and kaolins areas evaluation for use as pozzolanic materials, Zastita materijala 54 (1), 17-22

[11] Marku J., Jana N., Caja Sh. - "The alcaline attack of Erzeni riverbed aggregates used in concrete mixtures", XI Balkan Mineral Processing Congress, Durrës, Albania, May 2005

[12] Marku J. - "Concretes with mixed aggregates and the risk of ASR phenomenon manifestation", $6^{\text {th }}$ International Symposium "Materials and their use", Network of Materials Science and Engineering University of Prishtina, TU Bergakademie Freiberg, Polytechnic University of Tirana, Tirana, Albania, November 2006

[13] Marku J., Jana N. (2006) "Potential risk manifestation of alkali- silica reactions in concretes prepa- red by aggregates from different riverbeds in Albania", Albanian Journal of Natural and Technical Sciences AJNTS, No 19-20 (1-2), 45-57.

[14] Marku J., Jana N. (2006) "Complexities of alkalisilica reaction (ASR) manifestation on concretes produced with Erzeni riverbed aggregates", Bulletin of mathematics and natyral sciences, No.2, Faculty of Natural Sciences, Tirana, Albania,

[15] Marku J., Caja Sh. - "The influence of water - to cementitious material ratio on corrosion caused by Alkali-Silica Reaction (ASR) of mortars and concretes prepared by Erzeni riverbed aggregates", X YUCORR International Conference on cooperation of researches of different branches in the fields of corrosion and protection ofmaterials and the environment, Tara Mountain, Belgrade, Serbia, May 2008

[16] MarkuJ., Koçi M., DiloT.,CajaSh. - "The mineralogical content and the manifestation of Alkali-Silica Reaction in concretes prepared by Erzeni riverbed aggregates", XI YUCORR International Conference on cooperation of researches of different branches in the fields of corrosion, materials protection and environment protection, Tara Mountain, Belgrade, Serbia, May, 2009

[17] Marku J. -"Influence of the concrete mix design on Alkali-Silica Reactivity", The International Conference of BENA (Ballkan Environmental Association) - Pollution management and environmental protection, Tirana, September 2009

[18] Marku J., Vaso K. -"The influence of aggregate to cement ratio on corrosion caused by alkali - silica reaction (ASR) of mortars and concretes prepared by Erzeni riverbed aggregates", Second International Congress "Engineering, Ecology and Materials in Processing Industry", JahorinaMountain, Bosnia \&Herzegovina, March 2011

[19] Marku J. (2011) "Influence of the concrete mix design on Alkali-Silica Reactivity (ASR)", Journal of Environment Protection and Ecology, JEPE, Vol 12, No.2, 342-351.

\section{IZVOD}

\section{ALKALNO-SILIKATNI AGREGATI IZ KORITA REKE ERZENI (ALBANIJA) I MOGUĆNOST NASTANKA KOROZIJE U BETONU PROIZVEDENOG OD NJIH}

Razlozi ekološke efikasnosti i cena goriva vodio je industriju građevinskih sirovina da razvijaju nove tehnologije za proizvodnju cementa. Ovi cementi, koji se proizvode, imaju visok sadržaj alkalija, koji u kombinaciji sa nekim vrstama agregata mogu uticati na hemijski sastav vode za betonsku mešavinu, koja može uzrokovati dugoročne štetne efekte na betonskim konstrukcijama.

U ovom radu je sažeto pregledan deo naučno-istraživačkih ispitivanja obavljen na mogućnosti ispoljavanja štetnih efekata izazvanih alkalno - silikatnih reakcija ( ASR) u betonu napravljenog od visoko alkalnih cementa $i$ agregata iz korita reka u Albaniji, posebno onih agregata iz reke Erzeni, koji su najviše eksploatisani u Albaniji. Tretman ove teme je bio nužnost $i$ veoma važan za građevinarstvo u Albaniji, gde se proizvedi do polovne količina tradicionalno niskih alkalnih cementa. Posebno u periodu tranzicije, kada su visoko alkalni cementi počeli da se koristi i iz uvoza i iz domaće proizvodnje, smatra se veoma važnim proučavanje podobnosti korišćenja agregata iz reka u betonu proizvedenih sa visokim sadržajem alkalnog cementa, jer ne postoje načini sprečavanje ASR ako konkretno nije postavljen.

Rezultati i preporuke ovih ispitivanja služe da se poveća svest graditelja da je potrebno pravilno istražiti, sa ove tačke gledišta, sve sirovine pre izgradnje objekta. Oni, takođe, doprinose zaštiti životne sredine $i$ predlažući alternativne agregate iz korita reke pomažu $i$ da se izbegne propadanje, u roku, betonskih konstrukcija.

Ključne reči: alkalno - silicijumska reakcija (ASR), rečni agregati, silikatni agregat, krečnjački agregati.

Pregledni rad

Primljeno za publikovanje: 17. 07. 2014.

Prihvaćeno za publikovanje: 21. 09. 2014. 